\title{
Is it all going south? Four future scenarios for Antarctica
}

\section{Daniela Liggett}

Gateway Antarctica, University of Canterbury, Private Bag 4800, 8140 Christchurch, New Zealand

\section{Bob Frame}

Landcare Research, PO Box 69040, Lincoln 7640, New Zealand

(frameb@landcareresearch.co.nz)

\section{Neil Gilbert}

Constantia Consulting, 310 Papanui Road, Christchurch 8052, New Zealand

\section{Fraser Morgan}

Landcare Research, Private Bag 92170, Auckland Mail Centre, Auckland 1142, New Zealand

Received December 2016; first published online 11 September 2017

\begin{abstract}
The future is uncertain for Antarctica, with many possibilities - some more plausible, others more preferable. Indeed, the region and its governance regime may be reaching (or may have reached) a crossroads moment as a result of a series of challenges, including the changing Antarctic climate and environment, increasing human activity, shifting values among Antarctic states and a low-cost, somewhat benign governance regime (the Antarctic Treaty System). Within this context there are a number of interdependent drivers that are likely to influence Antarctica's future over, say, 25 years: global environmental and socio-economic developments; Antarctic governance; Antarctic research, including national Antarctic programme operations; and Antarctic tourism. The research presented here involved a thorough examination of Antarctic literature on current Antarctic developments and challenges, and an assessment of global trends. Scenarios were developed through a facilitated workshop process. From these, four future scenarios were developed based on interactions between these drivers. The resulting scenarios provide a dynamic, evolving possibility space to be explored as a means of understanding where Antarctic issues might evolve, depending on the growth or diminishing importance of drivers. In turn these suggest that more structured polar futures are needed based on formal quantitative and qualitative data.
\end{abstract}

\section{Introduction}

Within the global futures literature there is a very small subset examining developments in the polar regions. Rapid change in the Arctic has prompted the establishment of the Arctic Futures Initiative by the International Institute for Applied Systems Analysis, and numerous publications debate the implications of potential environmental, political and socio-cultural developments in the Arctic (Arbo, Iversen, Knol, Ringholm, \& Sander, 2013; Avango, Nilsson, \& Roberts, 2013; Young, 2013). However, so far only very few publications have explored Antarctic futures, despite the political and environmental changes and the increase in human activity in the region (Chown et al., 2012). Tin, Liggett, Maher, \& Lamers's (2014) volume on environmental futures of Antarctica is a first step in the direction of offering scenarios for possible future developments in Antarctica, but this is a long way from advancing the investigation of Antarctic futures to the level that research into Arctic futures or climate change futures more generally - currently occupies. This paper details work by a small group of researchers (three Antarctic experts in ecological and social sciences, environmental management and policy, and one futures researcher) to further Antarctic futures research. This paper presents the results of an intense period of research involving individual work in our respective areas of expertise, and a facilitated workshop to share the results of individual preparatory work and come to a consensus about the most important factors in the development of human activities in Antarctica and the structure and content of the resulting scenarios.

To undertake an initial assessment of Antarctic futures we have looked across multiple sources of information and have attempted to see how they could unfold in certain situations. We know that the future is uncertain, but it is important to explore the potential bounds in which an uncertain future could stretch so that future investments and programmes have the highest utility possible. These bounds can be tested in an examination of alternative futures, which necessarily involves identifying the key drivers that will shape these futures. Identifying drivers that will influence the character and scope of human engagement with Antarctica over the next few decades and exploring alternative Antarctic futures require an intimate understanding of the various aspects of human engagement with Antarctica. Many strategies use alternative futures as part of their risk management strategy for horizon 
scanning and emerging issues analysis, and to identify wild cards - low-probability, potentially high-impact risks that move us towards or away from a particular future state. A careful examination of the literature on current Antarctic developments and challenges (including a historical timeline of key events in the Antarctic, possible Antarctic futures and 'futuring' in general), helped identify probable drivers of change in the overall Antarctic landscape. It has also informed discussions on a set of Antarctic futures through a workshop process by the authors. From this we derived the key drivers for global developments of significance for Antarctica to be:

- global environmental and socio-economic trends that are likely to have an impact on Antarctica

- potential shifts in the Antarctic Treaty System (ATS) governance

- Antarctic research, including national Antarctic programme operations

- tourism in Antarctica.

For each of these, we reviewed the political, economic, social, technological, legal and environmental (PESTLE) dimensions of change (Sridhar, Sachithanandam, \& Mageswaran, 2016) to develop a set of four alternative scenarios (Slaughter, 2008). The paper addresses each driver in turn, then synthesises the results by developing four possible coherent scenarios, which we then examine as a set as has been used in other domains (Peterson, Cummings, \& Carpenter, 2003; Reed et al., 2013). Finally, we draw some conclusions on the challenges facing Antarctica in the future. This paper is intended to stimulate thinking and conversations on some very complex issues. By looking across multiple scenarios we attempt to open up the possibility for foresight on possible implications of strategic decisions about Antarctica in the near future. It should be stressed that these can never be absolutes but are constructs, or experiments, within which options can be explored and assessed.

\section{Global environmental and socio-economic trends}

In our brief assessment of future global trends we have drawn on the large body of scholarly literature on foresight research and futures studies. The majority of these focus on the 20- to 100-year range, including, among others, Adam \& Groves, 2007; Bell, 1986; Center for Health and the Global Environment, 2006; Ebi et al., 2014; Frame, 2008; Johansen, 2012; Kriegler et al., 2014; Moriarty \& Honnery, 2014; Nelson, 2010; Randers, 2012; Slaughter, 2008; and Weeks, Malone, \& Welling, 2011. Taken together these comprise a wide range of sectors and contemporary phenomena, such as climate change, environmental limits, demographics, economic development, access to resources, education and health, as well as assumptions about global governance and a continuation of current political models.

These studies have assumed no major global disruptions to the status quo and have also used widely accepted reports (for example, as found at www.oecd.org) as source material. We have not considered shifts that may occur as a result of changes in the political landscape, such as 'Brexit' or the election of Donald Trump as President of the USA. We see these, in a short-term context, as perturbations within the system, while our interest lies in long-term systemic change to which, of course, these short-term events may or may not lead.

In the global context Antarctic issues do not currently feature high on a list of critical priorities for many states or multinational corporations. Although Antarctica is considered to be of strategic importance to some countries (see for example, Fogarty, 2011), it is modest in comparison to matters such as health, food security, and access to education and water for much of the world's population. However, national and international priorities, along with global developments, have repercussions for how Antarctica's future unfolds. Consequently, any exploration of Antarctic futures requires an assessment of the global context within which human engagement with Antarctica will be positioned. However, this is not the main focus of this paper and is considered in much greater detail elsewhere, so we do not dwell further on these complex issues.

Key issues that are likely to define the global political, environmental and socio-economic order in the future have been drawn from the global outlooks listed above and are summarised in Table 1 (Adam \& Groves, 2007; Bell, 1986; Center for Health and the Global Environment, 2006; Ebi et al., 2014; Frame, 2008; Johansen, 2012; Kriegler et al., 2014; Moriarty \& Honnery, 2014; Nelson, 2010; Randers, 2012; Slaughter, 2008; Weeks et al., 2011). We acknowledge that they are generalisations of an anthropocentric world wrestling with how best to manage Antarctica and its assets in the face of multiple pressures elsewhere. The global context in Table 1 is neither judgemental nor authoritative, and merely intends to frame plausible, possible futures. These are placed in the middle of future options to provide the global context within which possible futures can be situated and in which investigations can be made about the future of Antarctica. More radical or unexpected events can be layered on top of this architecture, though that is not considered in depth here.

\section{Potential shifts in the Antarctic Treaty System}

For the seven Antarctic claimant states (Argentina, Australia, Chile, France, New Zealand, Norway and the UK) there is a significant benefit in maintaining a strong and effective ATS (see Appendix for tables of Antarctic Treaty Parties). The tentative political and legal nature of Antarctic territorial claims is far easier to manage within the framework of international cooperation provided by the Antarctic Treaty and its associated agreements (Conforti, 1986; Hemmings, 2014; Watts, 1992). The Antarctic Treaty (signed in 1959) is often regarded as one of the most successful international agreements ever made. For nearly 60 years it has provided the framework for peaceful 
Table 1. The global context for Antarctic futures to 2040.

\begin{tabular}{|c|c|}
\hline Political & $\begin{array}{l}\text { A neoliberal-dominated world order with few exceptions, dominated by a waning United States } \\
\text { of America and a growing China, though not without some issues. Continued global terrorism, } \\
\text { including cyber, biological and armed events. The influence of the European Union is waning. } \\
\text { Hollowed-out nation states are increasingly replacing an electoral system with issues-based } \\
\text { voting. New partnerships emerge between previous foes, such as environmental NGOs and } \\
\text { defence forces. }\end{array}$ \\
\hline Economic & $\begin{array}{l}\text { Increasing economic disparity between top and bottom household incomes, resulting in } \\
\text { dropping GINI coefficients among OECD countries. A highly constrained economy for basic } \\
\text { products. Low global growth on average over the last three decades. Marine resource } \\
\text { exploitation and aquaculture continue unabated, with an ongoing reduction in Northern } \\
\text { Hemisphere stocks and aquaculture in the Southern Ocean being considered. }\end{array}$ \\
\hline Social & $\begin{array}{l}\text { Population growth continues largely unabated, with Asia and Africa seeing the most growth and } \\
\text { a decline in Europe and the Americas. An intensely interconnected world has resulted in a } \\
\text { melding of identities and a reduction in the overall authority of the nation state. An increase in } \\
\text { gated communities, especially in mega-cities, with a significantly reduced population living } \\
\text { rurally. }\end{array}$ \\
\hline Technological & $\begin{array}{l}\text { Huge advances in information technology, genetic engineering and nanotechnology, including } \\
\text { low-cost viable DNA cloning. Bit-coin } 3.0 \text { has replaced the USD as the main global currency. } \\
\text { 'Peak car' has passed. Asteroid mining is used by a few high-tech global corporates to obtain } \\
\text { vitally important rare-earth metals for new devices. }\end{array}$ \\
\hline Legal & $\begin{array}{l}\text { Global treaties still exist but have become very weak and are largely ignored, except by nation } \\
\text { states. The UN system is visibly flawed but has not been reformed because of a lack of strong } \\
\text { leadership. There is a huge increase in trans-boundary crime. Personal income taxation is } \\
\text { replaced by resource usage taxation in the G20. }\end{array}$ \\
\hline Environmental & $\begin{array}{l}\text { Climate change is accepted as a serious threat, with an increase in average global } \\
\text { temperatures of } 4^{\circ} \mathrm{C} \text { anticipated by } 2100 \text {. Targets to address climate change issues are } \\
\text { largely tokenistic. Bar a significant increase in wild weather events there are, as yet, no other } \\
\text { material manifestations of warming. Basic food production has been severely constrained } \\
\text { through water wars and diminished access to raw materials. Factory farming and 3D printing } \\
\text { are widespread. Pristine wilderness areas have reduced to a few national World Heritage } \\
\text { parks. All landscapes have been influenced by human activity. Anthropogenic effects are } \\
\text { documented on all life forms. }\end{array}$ \\
\hline
\end{tabular}

international cooperation in the region. Under the auspices of the Antarctic Treaty several additional agreements have been signed to regulate human activities on the continent and in the Southern Ocean. Collectively this suite of international agreements is referred to as the ATS (Beck, 2014).

The ATS has been successful in terms of:

- maintaining peace in the region for nearly 60 years

- fostering international cooperation on logistics and scientific research

- facilitating research that is of global benefit

- demonstrating international leadership on the sustainable management of marine resources

- continued emphasis on high standards of environmental management

- attracting new countries to become signatory states to the Antarctic Treaty and the Protocol on Environmental Protection (hereafter, the 'Protocol').

However, the ATS is facing a host of emerging challenges that will need to be recognised and responded to if the system is to retain its effectiveness and international credibility (Chown, 2013; Chown et al., 2012; 2017). First, membership in the ATS continues to grow, with Kazakhstan (27 January 2015), Mongolia (23 March 2015) and Iceland (13 October 2015) having most recently acceded to the system. This means that the original 12 signatory states (including the seven claimant states) are now outnumbered by more recent signatories (Fig. 1) (Davis, 2014). Associated with this growing membership is a subtle shift in the Antarctic Treaty Parties' motivations to participate in the ATS. The original 12 signatories and states acceding in the first two decades after the birth of the regime were largely driven by a perceived geopolitical need to prevent others from gaining strategic advantages from the Antarctic (Bulkeley, 2010) and managed the Antarctic through cooperation on scientific research, while states joining the ATS over the last three decades have been more focused on the resource potential the Antarctic holds (Dodds, 2006; Dodds \& Collis, 2017). This can be seen in the significant growth, for example, in membership of the Antarctic Treaty during the 1970s and 1980s, when resource management discussions (fishing and minerals) were a priority issue (Fig. 1).

Second, a challenge is posed by the increasing pace of climatic and environmental change in the region, which has implications for native biodiversity and the increasing establishment of non-native species. Changing environmental conditions also have logistical consequences for accessing and operating in the region, as well as for the perceived value of Antarctica for scientific research (Turner et al., 2014). 


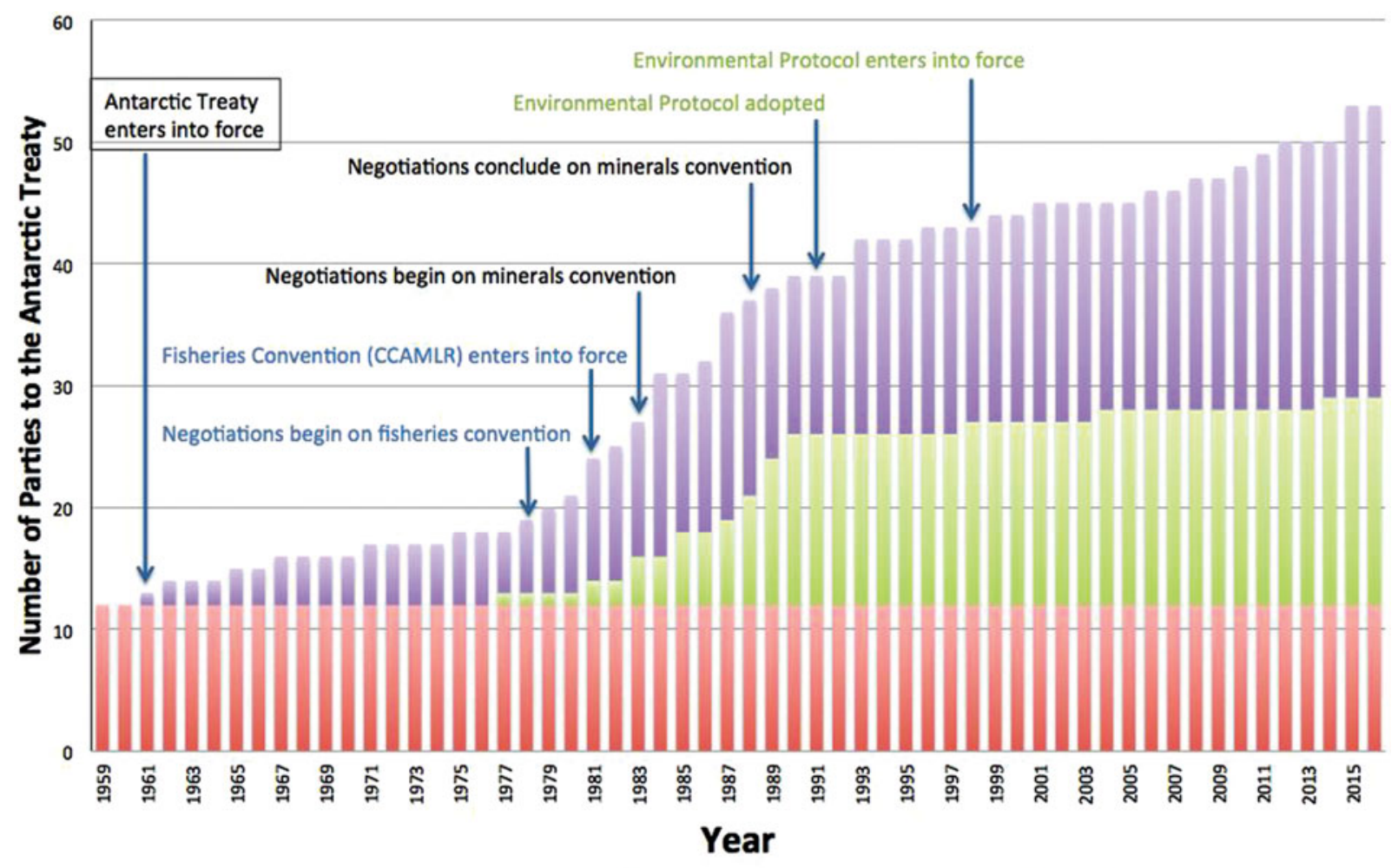

= Original signatories $\quad$ Consultative Parties Acceding States (non-Consultative Parties)

Fig. 1. Growth in membership of the Antarctic Treaty since 1959 (based on information retrieved from the Antarctic Treaty System database)

Third, investment in the political system is not high with treaty parties having a preference for a low-cost system, with shorter meetings (the meeting length was reduced from ten to eight days in 2012), increasing intersessional e-groups and low investment in the Antarctic Treaty Secretariat due to the legal issues limiting its role. Investment by parties in Antarctic governance is relatively modest compared to other international arrangements. Members' contributions to the annual budget of the Buenos-Aires-based Antarctic Treaty Secretariat, which supports the Antarctic Treaty Consultative Meetings (ATCM) and the Committee on Environmental Protection (CEP), is less than US\$1.4 million (ATCM, 2016), a rather limited budget when compared to members' contributions to the Commission on the Conservation of Antarctic Marine Living Resources (CCAMLR) general fund of approximately US\$3.2 million (CCAMLR, 2015) and to the general fund of the Convention on Biological Diversity of approximately US\$13.2 million (UNEP, 2015). This, along with the growing number of member states, may be linked to, and culminate in, a slowing political process, which is manifested by ATCM decisions taking an increasingly long time to enter into force. For instance, the sixth Annex to the Protocol on Environmental Protection to the Antarctic Treaty, which focuses on liability for environmental damage, was concluded in 2005 but as at 23 April 2017 only 13 of 28 treaty parties have taken the action necessary to bring the Liability Annex into force (ATS, 2017). Likewise, despite years of discussion, CCAMLR has struggled to designate Marine Protected Areas in the Southern Ocean, risking its conservation credentials (Brooks, 2013). The 2017 triumph of reaching consensus in support of the creation of a Marine Protected Area in the Ross Sea represents some progress in CCAMLR's struggle to balance conservation interests and resource exploitation, but it does not resolve the tensions between environmental protection and fishing.

Fourth, while the parties readily address straightforward policy matters, they have not yet made progress on difficult issues such as the regulation and management of biological prospecting in Antarctica - mainly because of divided opinions among Antarctic Treaty Parties as to the need for more specific rules on access and benefit sharing other than that already resulting from the obligation to give prior notification and share scientific results (Jabour, 2015b; Puig-Marco, 2014). The low-hanging fruit are readily grasped, while tough questions around sovereignty, presence in Antarctica or even climate change may only be touched on during ATCMs without consensus being reached.

Fifthly, and finally, tourism activities continue to attract significant discussion time at ATCMs, but with few management or policy outcomes, while the industry itself continues to expand and become more influential (Jabour, 2014). Tourism matters are explored in their own section later in this paper.

If the above challenges cannot be addressed by the parties, the system is at risk of becoming increasingly 
Table 2. The future of the Antarctic Treaty System to 2040.

\begin{tabular}{|c|c|}
\hline Political & $\begin{array}{l}\text { Growth in membership has the potential to stymie the effectiveness of the ATCM given its } \\
\text { consensus decision-making provisions. Without renewed investment (political and financial), } \\
\text { many of the key challenges facing the system may fail to be adequately addressed, bringing } \\
\text { into question the effectiveness and relevance of the ATS. }\end{array}$ \\
\hline Economic & $\begin{array}{l}\text { There is potential to see an increasing shift towards commercial exploitation of the region, } \\
\text { including through terrestrial and marine bioprospecting, marine resource harvesting and } \\
\text { land-based tourism as a result of the growing number of treaty parties, the majority of which } \\
\text { favour an economic return (as opposed to a research/knowledge benefit) on their Antarctic } \\
\text { investments. In the } 2040 \text { s we may see some countries suggesting that they may call for a } \\
\text { conference to review the Protocol (and its mining prohibition) after } 2048 \text {. }\end{array}$ \\
\hline Social & $\begin{array}{l}\text { The dominance of tourism and fishing as the primary Antarctic activities in the } 2020 \text { s may well } \\
\text { lead to a growing social acceptance of a more commercial element to Antarctic activities. } \\
\text { Despite ongoing advocacy by the e-NGO groups, society will potentially be less concerned } \\
\text { about maintaining 'the last great wilderness' than it was in the 1980s. Discussions at Antarctic } \\
\text { Treaty meetings are likely to focus more on access and benefit sharing of Antarctic resources } \\
\text { as a result. }\end{array}$ \\
\hline Technological & $\begin{array}{l}\text { It is possible that advances in information technology will allow treaty parties (individually and } \\
\text { collectively) to have an improved understanding of climate and environmental change in } \\
\text { Antarctica, and that modelling will provide a clearer indication of future anticipated change. } \\
\text { This may provide an impetus to the political system to ensure it adequately responds to this } \\
\text { new knowledge. }\end{array}$ \\
\hline Legal & $\begin{array}{l}\text { There is a risk that Antarctic Treaty law becomes increasingly less valid or relevant. } \\
\text { Membership growth means policy and management decisions are already taking longer to } \\
\text { negotiate and even longer to enter into force. }\end{array}$ \\
\hline Environmental & $\begin{array}{l}\text { By } 2040 \text { the effects of a changing Antarctic climate will be significant across many parts of the } \\
\text { continent and Southern Ocean (including through further ice-shelf collapse, warming seas, } \\
\text { ice loss from the continent and changing native biodiversity). ATS decision-making processes } \\
\text { may not be able to keep pace with these changes. }\end{array}$ \\
\hline
\end{tabular}

ineffective (Liggett \& Stewart, 2017a), with parties and industry groups acting increasingly independently of each other and the ATS (Table 2).

At the upper end of the timescale, there is merit in examining potential attitudes of the treaty parties and parties to the Protocol in the late 2040s. First, it is noted that misunderstandings sometimes arise on the significance of 2048, which is variously referred to as the date that the Antarctic Treaty expires, the date the Protocol expires, the date the mining ban expires or the date when the Antarctic Treaty has to be renegotiated. Not one of these interpretations is correct. The reality is that the Protocol, like the Antarctic Treaty itself, has no end date. However, the Protocol does provide for any Antarctic Treaty Consultative Party (ATCP) to call for a conference to 'review the operation of the Protocol' after the expiration of 50 years from the date of the Protocol's entry into force, that is, after 14 January 2048 (Article 25 of the Protocol). The Protocol mandates that the prohibition on mineral resource activities can only be overturned if there is in place a binding legal regime to manage such activity (for more detail see Jabour, 2015a; Scott, 2015). Partly as a result of this persistent confusion, the ATCPs reaffirmed their commitment to the Protocol's prohibition on mining at their 2016 meeting (ATCM Resolution 6, 2016). Nonetheless, it is quite feasible that some parties, either individually or as a group, may wish in the future to implement the review procedures set out in the Protocol and seek to modify aspects of it, including the mineral resources prohibition.
Because of the opportunity for any party to call for a review conference after January 2048, that year has the potential to be a milestone in terms of testing the resilience of the Antarctic governance regime. The extent to which the Protocol's review mechanism is utilised - as well as the issues that are raised at any such review and the persistence of parties in pursuing their particular agendas could either be unifying or divisive. Either way, the 2040s are likely to see increased political attention being paid to Antarctic matters in anticipation, and it will be important for like-minded states to prepare for a potentially significant test of the system. If the ATS is to remain an effective governance regime for the region and retain its international standing, then the parties will need to take concerted action to address these challenges, including through increased resourcing, innovative policymaking and collective determination. The next few years will be a crucial indicator of the most probable outcomes for the ATS in the longer term.

\section{Antarctic research in the future}

Significant changes are expected to the current approaches to undertaking science in Antarctica and to the topics of interest. A changing climate and its effects on Antarctica and the life found within Antarctica will continue to be a key focus (Hodgman, 2016; Kennicutt et al., 2014b). There is a move to a longer science season, which we expect will extend to year-round science activities, with large field events occurring throughout the winter in 
the next 10-15 years (COMNAP, 2016). Alongside an extended field season, there is a move towards greater support (that is, temporary bases) at sites of key scientific interest (COMNAP, 2016; Kennicutt et al., 2016). This is likely to continue alongside the expected slow growth in new permanent bases on the continent from existing or new treaty parties.

Technology will continue its rapid advance. Technologies and approaches currently used were unthinkable a few decades ago. An example is the increasing use, and sophistication, of automated aquatic and aerial sensor platforms (drones/submersibles) (Augustine et al., 2012; COMNAP, 2016; Kennicutt et al., 2016; National Academy of Sciences, 2011), which enable increased spatial and temporal resolution. In the short term the rise of these technologies will increase the number of scientists visiting the continent, but this may well plateau as the sharing of the platforms on which the scientific instruments are attached increases. The use of these technologies will also increase throughout the winter months (COMNAP, 2016; Kennicutt et al., 2016).

Networks of fixed monitoring stations will develop over the next ten years, which will aim to provide a context for the changes occurring in Antarctica (COMNAP, 2016; Kennicutt et al., 2016). These stations will rely on significant advancements in telecommunications, and on battery and power technologies, which will need to be developed over the next decade. The advances made to remove current constraints with regard to telecommunications, batteries and power will have significant impacts for the operational realities of Antarctic science and the level of human activity in Antarctica (COMNAP, 2016; Kennicutt et al., 2016).

Telecommunication networks within Antarctica and out of Antarctica are currently inadequate for the types of science questions and information requirements that need to be addressed over the next two decades (COMNAP, 2016; Kennicutt et al., 2016). In order for the types of technological support requirements laid out in the COMNAP Roadmap Challenges to eventuate, significant changes to and investments in the ability to source, store and move data around the continent, and then transmit it to and store it in, say, New Zealand, will be required. Fortunately, it appears that emerging technologies are likely to be available within the next few years to achieve a relatively high-bandwidth, low-earth-orbit constellation of satellites that ensure constant Antarctic and Southern Ocean coverage. This is also expected to be achieved via significant reductions in the cost of satellite technology and in the logistical costs of getting the technology into space in the first place.

If technological solutions can be found to the three other primary constraints on Antarctic research, namely telecommunications, power storage and power generation, we will see a rise in more remote and autonomous science being undertaken in Antarctica, which may lead to fewer scientific personnel. This would be balanced by an increase in technical staff needed to support the increase in the use of aquatic/aerial drones, long-term monitoring stations or mobile terrestrial science platforms. Such technological solutions to current challenges facing Antarctic researchers are likely to emerge from the technology sector outside the Antarctic realm and are likely to draw on initiatives by private enterprises and private-public partnerships, think tanks and research/tertiary institutes.

Large-scale 'keystone' projects such as ANDRILL (the Antarctic Geological Drilling project) and IceCube (the South Pole Neutrino Observatory) are expected to continue for two decades (COMNAP, 2016; Kennicutt et al., 2016). These types of projects may continue past this point, but their scope and structure will depend on funding, collaboration and logistical support. The strength of a country's support for such ambitious projects will depend on the wider science context, as outlined in Table 3. Simple economics will continue to have a significant impact on the science projects that can be undertaken in Antarctica, and while remote science will become more prominent, on-site research will continue to depend largely on energy prices (that is, the cost of access and presence).

With more activities occurring in Antarctica and the Southern Ocean, the need for a greater understanding of the scale of human activity will become more pressing (COMNAP, 2016; Pertierra, Hughes, Vega, \& OlallaTárraga, 2017; Tin et al., 2014; Woehler, Ainley, \& Jabour, 2014). Similarly, a greater focus on health and safety in Antarctica will be inevitable as a result of more stringent domestic health and safety legislation (COMNAP, 2016). Geo-fencing of activities to permitted geographical coordinates, automated warnings of potential Antarctic Specially Protected Area (ASPA) and Antarctic Specially Managed Area (ASMA) incursions, and one-touch coordinates being sent to emergency responders may be direct results of these changes. Over the long term (40plus years), and depending on technological advances, we expect to see the use of zero-emission electrical drones for the movement of people and their equipment to reduce the level of human impact occurring in Antarctica, as reported by King (2016). The continued interest of Antarctic players to engage in Antarctic science will depend on science funding, public and political will, and strong scientific/logistical collaboration with international partners (COMNAP, 2016; Kennicutt et al., 2014a, 2014b; National Academy of Sciences, 2011). If any of these aspects are diminished, we expect a reduction in the scale and scope of scientific activities on the continent.

To date, Antarctic research has been largely carried by the state - from Antarctic research funding to logistics support through national Antarctic programmes. In the near future, we may be faced with a shift from government-funded research to private funding, either through philanthropic funding (in several countries this is already happening) or through funding made available by businesses with an interest in returns on their investment. While such a shift is likely to be an incremental, insidious change over time, it would be very influential in that it might rewrite research priorities and reset the underlying 
Table 3. The future of Antarctic science to 2040.

\begin{tabular}{|c|c|}
\hline Political & $\begin{array}{l}\text { There is an increase in collaboration between countries in Antarctica to share the costs of } \\
\text { undertaking science in Antarctica. This is mainly born out of the reduced public and political } \\
\text { will to spend significant resources in Antarctica without economic gain. While potentially } \\
\text { 'international' in nature, these collaborations will coalesce around existing geopolitical blocs. } \\
\text { New partnerships emerge to support scientific activities through logistical support provided by } \\
\text { tourism aircraft/vessels and defence activities in the region. The Scientific Committee on } \\
\text { Antarctic Research (SCAR) continues to grow and develop to focus the limited resources } \\
\text { available for Antarctic science. }\end{array}$ \\
\hline Economic & $\begin{array}{l}\text { Because of low global economic growth and a decreasing tax base for Antarctic science in } \\
\text { some countries, the level of funding for Antarctic science decreases (after taking inflation into } \\
\text { account). To a large extent the long-standing players in the ATS still do not view Antarctica as } \\
\text { an economic opportunity. Mining activities within Antarctica are seen as a possibility, but } \\
\text { technological advancements are reducing the need to extract mineral resources in Antarctica } \\
\text { and rare-earth elements are increasingly acquired elsewhere (for example, through asteroid } \\
\text { mining). However, freshwater harvesting and geo-engineering are explored in Antarctica, and } \\
\text { bioprospecting, actively supported by commercial interests, has long become accepted } \\
\text { practice. }\end{array}$ \\
\hline Social & $\begin{array}{l}\text { Outside of the political structure individual scientists continue their strong collaboration, ignoring } \\
\text { country and political blocs. Science sceptics continue to be present in the public and support } \\
\text { political perspectives that view the scientific community (and, by extension, SCAR) as biased, } \\
\text { and work to limit access to the continent through a decrease in operational and research } \\
\text { funding. }\end{array}$ \\
\hline Technological & $\begin{array}{l}\text { The way science is undertaken and the questions asked are being transformed as a result of } \\
\text { technological change and the opportunities it brings. Improvements in telecommunications, } \\
\text { batteries and power generation provide the ability for year-round observations, and samples } \\
\text { can be taken more regularly, remotely, through the operation of mobile terrestrial science } \\
\text { platforms. Significantly improved satellite sensors that allow the sensing of subsurface water } \\
\text { and soil properties, the visualisation/tracking of megafauna, and microbial/invertebrate } \\
\text { communities will transform Antarctic science and allow a shift from focusing on individual } \\
\text { locations to studying regions. Flight networks across the continent have become well } \\
\text { established, and intra-continental flights become one of the features of operating in Antarctica } \\
\text { and undertaking multi-site research. }\end{array}$ \\
\hline Legal & $\begin{array}{l}\text { The Antarctic Treaty is still in effect but could become marginalised due to a lack of political will } \\
\text { and collaboration. Research is undertaken by individuals heading to Antarctica on } \\
\text { well-equipped private or commercial vessels and is sponsored by private investors, } \\
\text { benefactors or even commercial interests. }\end{array}$ \\
\hline Environmental & $\begin{array}{l}\text { The effects of climate change are visible to scientists in Antarctica through changes in terrestrial } \\
\text { and marine ice, biological activity and temperature records. Human activity has increased in } \\
\text { relation to } 2016 \text { levels, but has since plateaued. Increasing numbers of scientists, scientific } \\
\text { support personnel and tourists visiting Antarctica lead to greater incursions of non-native } \\
\text { species in Antarctica, affecting the endemic flora of Antarctica and eventually the fauna. } \\
\text { These incursions, along with the other effects of human activities, begin to present issues for } \\
\text { ongoing scientific research. Alongside the strengthening of the ASPA/ASMA system, SCAR } \\
\text { supports the development of inviolate areas where no human activity is permitted and only } \\
\text { mobile terrestrial science platforms (like the Mars rover) can enter. }\end{array}$ \\
\hline
\end{tabular}

structures and processes that enable Antarctic research to take place. It might also shift the balance of power with regard to Antarctic research as well as Antarctic governance. If private research funding from businesses, for example tourism operators, pharmaceutical companies or even oil companies, is to supplement governmental funding for Antarctic research, research priorities might change. Governments will need to be making firm decisions on what they want Antarctic research to be about, especially if future research funding is to be an amalgamate of public and private funding - or whether it continues to matter.

\section{Antarctic tourism futures}

Although episodic tourism preceded the signing of the Antarctic Treaty in 1959, regular organised commercial travel there began in the mid-1960s (Headland, 1992; Mason \& Legg, 1999, 2000; Murray \& Jabour, 2004; Reich, 1980; Tracey, 2001). Consequently, tourism is not mentioned in the Antarctic Treaty. Tourism regulation developed organically, but slowly, alongside tourism activities, although regulation generally lagged behind tourism development (Liggett \& Stewart, 2017b). The most important regulatory mechanism within the framework of the ATS addressing Antarctic tourism activities is the 1991 Protocol, which entered into force in 1998 and regulates all human activities undertaken by citizens of, or organisations based in, the Protocol's signatory states. Operationally, however, the treaty parties left the management of Antarctic tourism activities largely in the hands of the tour operators and the International Association of 


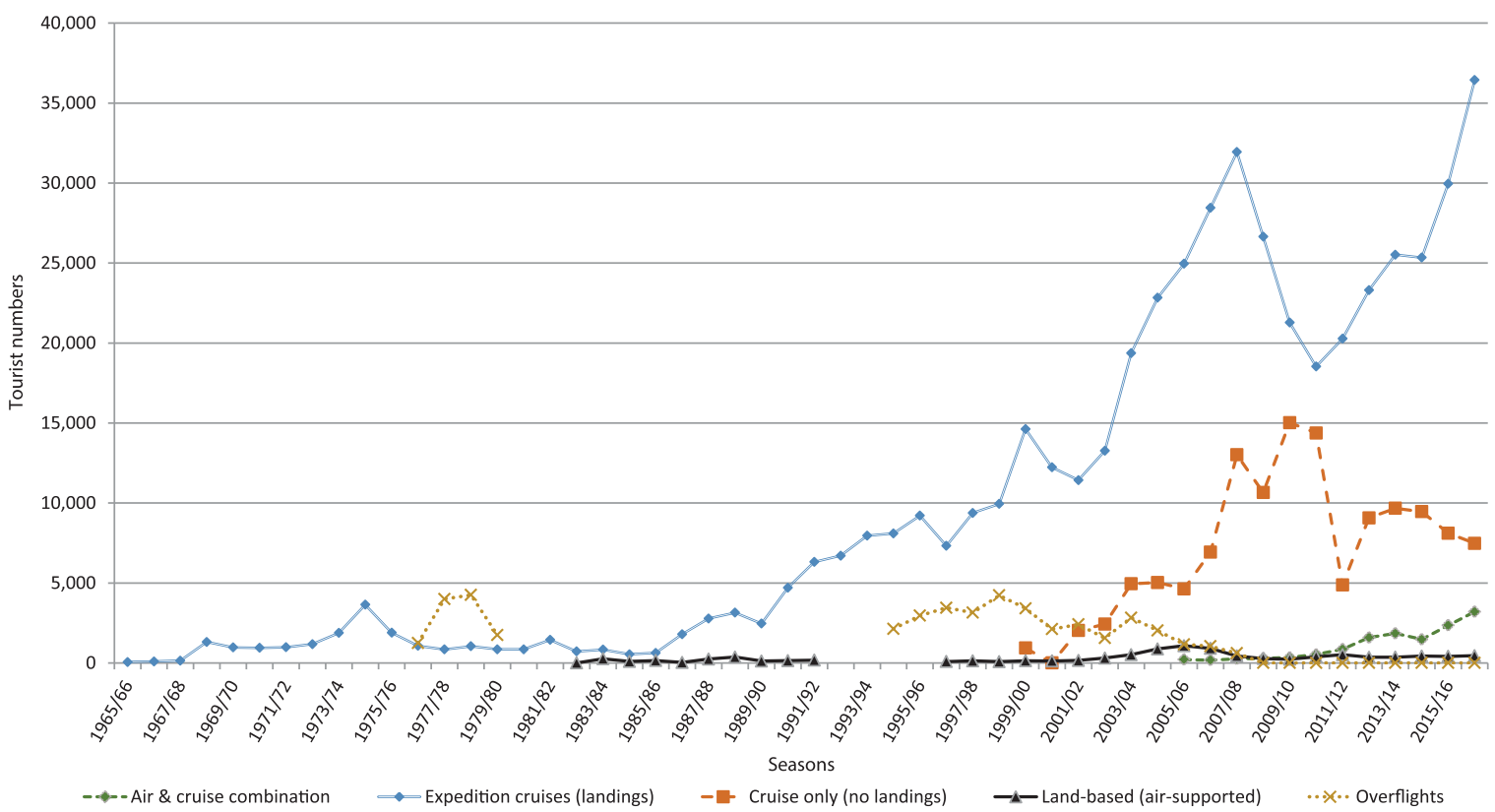

Fig. 2. Tourism development since the beginning of regular commercial tourism to Antarctica (based on IAATO data)

Antarctica Tour Operators (IAATO). IAATO was formed in 1991 by seven Antarctic tour operators and has now grown to a membership of 116 , including 49 member operators (Splettstoesser, 2000).

Over the last two decades Antarctic tourism has diversified substantially and grown in intensity (Liggett $\&$ Stewart, 2017a). The most significant tourism activity, both in terms of tourist numbers and operators involved, remains expedition-style cruise tourism, followed by cruise-only tourism (Fig. 2). Overflights in Antarctica completely ceased for a number of years after a DC-10 operated by Air New Zealand crashed into the flanks of Mount Erebus in 1979, killing all passengers and crew on board. In 1994, Qantas recommenced operating overflights but they never regained the popularity they enjoyed before the crash in 1979. Over the last decade, overflights have virtually faded into insignificance, if not non-existence, a development that, like all tourism developments, is demand-driven and may reflect a general unwillingness to spend money on flights if a more intimate touristic experience can be had for a slightly higher price.

The demand for Antarctic tourism is responsive to global economic and political developments, as evidenced by the significant drop in demand following the global economic crisis in 2008 (Figs 2 and 3). Due to the high investment required to operate tourism to Antarctica, supply is less elastic, especially among the smaller owneroperators who specialise in tourism to the polar regions. Nonetheless, significant regulatory changes in the operating environment have impacts on supply, as we have seen from the International Maritime Organization's ban on the use and carriage of heavy fuel oil in Antarctica, which came into effect on 1 August 2011 and resulted in a number of the larger multinational tourism companies that operate cruise-only vessels leaving the Antarctic tourism market (Fig. 3) (Liggett \& Stewart, 2017a).

Analysis of tourism trends over the last five decades suggests further growth in tourism numbers over the next decade, accompanied by further diversification of the tourism product (Bastmeijer \& Roura, 2004; Bertram $\&$ Stonehouse, 2007) and a greater volume of yachtbased tourism and individual (non-commercial) adventure tourism activities. Challenges arising from the growth and diversification of tourism include:

- an increased potential for devastating incidents and accidents (see for example, Republic of Liberia, 2009 and the Berserk 2011 expedition), resulting in the pressing need for closer collaboration between the different national Search and Rescue Coordination Centres responsible for operations in the Southern Ocean (Jabour, 2017)

- a greater probability of the introduction of non-native species or diseases (Hofman \& Jatko, 2000; Pfeiffer \& Peter, 2003)

- difficulties for ATCPs to regulate an increasingly diverse spectrum of tourist activities (Antarctic and Southern Ocean Coalition, 2005; ATCM, 2012)

- difficulties for IAATO to manage an increasingly diverse spectrum of tourist activities (ATCM, 2012; Haase, Lamers, \& Amelung, 2009)

- gateway cities (that is, a coastal or island port able by its proximity to the Antarctic to benefit from and control access to Antarctic and Southern Ocean resources, including fishing, tourism and scientific support [Chua, Shah, Husin, \& Rahman, 2015]) having to deal with waste brought back from Antarctica by tour operators (Bertram, 2005)

- gateway cities providing sufficient tourism infrastructure (including accommodation and other tourism 


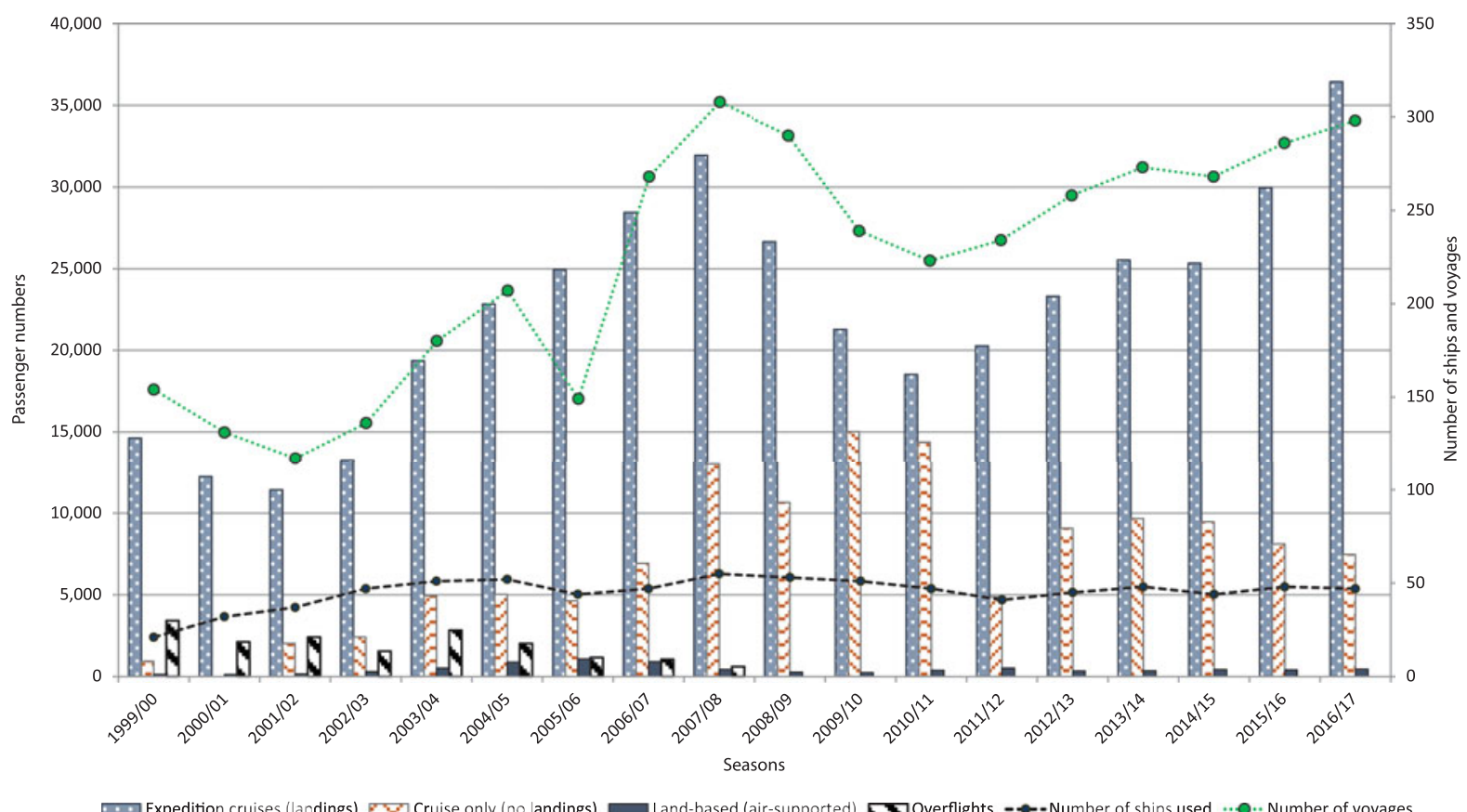

Fig. 3. Tourism development, including the number of vessels used, since the turn of the millennium (based on IAATO data)

services) during the peak tourism season (Swanson, Liggett, \& Roldan, 2015)

- legal implications and duties imposed on port states (under UNCLOS, the United Nations Convention on the Law of the Sea) and their consequences for gateway cities, particularly if memoranda of understanding on Port State Jurisdiction put more responsibility on the shoulders of gateway ports (Bertram, Muir and Stonehouse, 2007; Swanson et al., 2015).

Wild cards in the development of tourism over the next decade include the possibility of a devastating accident involving a cruise vessel, resulting in a loss of lives, which would undoubtedly provoke a more significant regulatory response and possibly a loss of faith in the management of Antarctic tourism by IAATO; or a significant environmental disaster resulting from Antarctic tourism operations (for example, a large fuel spill, the demise of one or several large penguin rookeries due to diseases introduced by tourism, rogue operators or individuals undertaking sport fishing/hunting in Antarctica), which would also propel policymakers into action.

Disregarding such wild cards, we expect the Antarctic tourism market to mature in the next decade and numbers to stabilise. We might then see a decline in tourist numbers around, or after, 2030. The expectation that Antarctic tourism numbers will plateau is based on research by Butler (1980), who studied tourism development at many destinations around the world and concluded that tourism development follows a destination life cycle of initial discovery and development (with a rapid increase in visitor numbers), followed by market consolidation and stagnation, after which a decline in visitor numbers is seen unless a destination is reinvented or rejuvenated. We hypothesise that this reinvention or rejuvenation is only possible to a very limited extent, considering the biophysical realities of Antarctica, and that it will most probably involve some environmental sacrifice (Table 4). While we have seen significant diversification of the Antarctic tourism product in the past (Liggett \& Stewart, 2017a), the changes we have seen have been tweaks in what types of adventures at land (for example, overnight camping, marathon running) or at sea (for example, kayaking) were offered and do not represent product reinventions. Antarctic tourism continues to be dominated by cruise tourism, which is increasingly supplemented with fly-cruise tourism. Considering the remoteness of the Antarctic continent and the necessity to access the continent by sea or air, ships are likely to remain key players in the Antarctic tourism market. Any dramatic change of the Antarctic tourism product is likely to involve shifting the main base for tourism operations from the ship to land, which will increase the environmental impact on the Antarctic continent. Due to the cost involved, and the absence of great fluctuations in the numbers of land-based tourists over the last three decades, we do not expect to see a significant future increase in land-based tourism activities. However, Antarctica will continue to attract adventurous and pioneering spirits, who will push the boundaries of what were considered humanly impossible feats of endurance, perseverance or daring in the past. These individual 'explorers' will challenge the political, legal, moral and economic boundaries within which national Antarctic programmes and commercial tour operators operate. If things do go awry, as was, for instance, the case with the 2011 Berserk expedition that 
Table 4. The future of Antarctic tourism to 2040.

Political The ATCPs and IAATO continue to share the responsibility for the management of Antarctic tourism. While the ATCPs still assume the ultimate regulatory power with regard to Antarctica tourism, a weakening of the ATS results in a lack of political will and commitment with regard to the regulation of Antarctic tourism. IAATO increasingly collaborates with, and operationally supports, a number of national Antarctic programmes, which, in turn, make some of their facilities, ports and airstrips available for tourism purposes. IAATO has the financial and human resources to increase its political influence and takes greater ownership in regulating (as well as managing) Antarctic tourism operations. Increasingly, international agreements that are not specific to Antarctica and are related to global shipping operations (for example, through the International Maritime Organization's regulations) gain significance and political muscle with regard to Antarctic tourism regulation.

Economic Tourism is likely to have peaked around 2030, and the market is now focusing on niche products, including some extreme sports tourism and adventure activities. Solo travel, monitored and supported from outside the Antarctic region through smart technologies, is gaining economic significance. Land-based tourism numbers remain relatively stable, but a small number of extreme sportspeople and adventurers are pushing the boundaries of the physically possible in Antarctica (with significant risks attached for the tourists/expeditioners themselves, as well as for national Antarctic programmes and other tourism companies operating in the vicinity). The semi-permanent facilities in the Patriot Hills have become a permanent facility operating year-round and offering meditation and yoga retreats in addition to supporting adventure tourism. The economic impact of tourism for gateway cities is still significant, especially for the South American gateway cities. The Asian market plays a significant role in Antarctic tourism. Asian operators have entered the market and offer luxury fly-cruise operations through South America and New Zealand/Australia, as well as longer around-the-world cruises from Shanghai and Kyoto.

Social

The dominance of tourism and fishing as the primary commercial Antarctic activities in the 2020 s leads to a growing social acceptance of a more commercial element in Antarctic activities. With the workplace becoming increasingly merged with the home, the ability to work from a distance using superfast global network technology enables those ordinarily too busy to travel to Antarctica to embark on world cruises that include Antarctica in their itinerary. The profile of the typical Antarctic cruise tourist changes: the majority of cruise tourists are well off, dynamic, mobile, young professionals from Asian countries, while the number of retired people visiting Antarctica decreases due to a lack of disposable income and time, brought on by changes in the legal and economic framework around retirement in many countries. Reminiscences of days gone by encourage some modern explorers to undertake Antarctic traverses without any modern technological support, relying only on materials and equipment used by the likes of Scott, Shackleton and Borchgrevink.

Technological Technological advances make travel to Antarctica safer and faster. Large passenger jets carrying over 100 passengers per flight to Antarctica are becoming more frequent, and a range of national and privately owned airlines offer Antarctic destinations on regular itineraries during the summer months. Antarctic adventure tourism is safer through smart wear, and continent-wide access to the internet through satellite technology and radio networks makes it easier to access reliable weather and related-risk information. GPS tracking technology is worn by some tourists, but most (especially independent travellers) actively avoid any tracking or monitoring.

Legal Legal challenges to the reporting and monitoring responsibilities of tour operators continue to dominate political discussions. Fines payable by rogue operators who disregard reporting or operating requirements have been increased by many ATCPs, and collaboration by the Southern Rim states in the prosecution of offenders reduces the number of offences. However, those with sufficient financial resources to buy legal representation and advice increasingly test the legal framework. Continued ambiguity about jurisdiction in Antarctica creates additional loopholes and consumes precious resources when prosecutable incidents do occur.

Environmental The effects of climate change are widely felt across Antarctica. The waters around the Antarctic Peninsula are more easily navigable, making access to areas south of the Antarctic Circle possible for large vessels that are not ice-strengthened. Gentoo penguins dominate the South Orkney Islands and most of the northern parts of the Antarctic Peninsula, and tour operators who wish to offer opportunities to see Adélie or chinstrap penguins have to push further and further south. Due to the warming Antarctic Peninsula, the propagation of seeds brought in by accident is much greater, and tourists (as well as scientists) have inadvertently introduced a range of flowering grass species, which now outcompete the native species. The sea ice in the Ross Sea region has become unpredictable, with strong westerly winds able to move sea ice so quickly that tourist vessels are becoming trapped in ice on a semi-regular basis. 
had been spearheaded by Jarle Andhøy from Norway and resulted in the loss of three lives, the respective case is likely to be discussed at an ATCM. In Andhøy's case, New Zealand argued that he did not heed any warnings from the authorities regarding his planned expedition (New Zealand, 2012). In addition, his expedition to Antarctica had proceeded without a permit or without preparing the required environmental impact assessment (Norway, 2012). The Norwegian authorities consequently fined Andhøy NOK25,000 for failure to follow procedure and obtain a permit before travelling to Antarctica (Norway, 2012), which is a small victory for the ATS showcasing that there will be consequences for non-compliance, although NOK25,000 is arguably a rather small fine to pay for such gross negligence. The latter point has been raised by New Zealand in a working paper (New Zealand, 2012), after Andhøy visited Antarctica again in 2012 with the yacht Nilaya, once again without filing an environmental impact assessment or the required authorisation. New Zealand (2012) called for parties to agree the required action preventing Andhøy from ever again organising an unauthorised Antarctic expedition. Further, that any unauthorised expeditions should be treated as serious threats to the integrity of the ATS and should be prosecuted. Resolution 10 (2012) specifically focused on yachting expeditions and recommends to parties to ensure that all yacht operators consult and utilise an agreed-upon checklist for safe yacht voyages to the Antarctic in their planning.

Multiple factors determine the future development of tourism in Antarctica. The increasing pace of climate and environmental change in the region has significant implications for native biodiversity and the increasing establishment of non-native species. Changing environmental conditions also have logistical implications for accessing and operating in the region, as well as for the perceived value of Antarctica for scientific research and tourism operations (Bertram, Muir, \& Stonehouse, 2007; Liggett, 2011). A similarly important role is played by the availability of infrastructure, such as tourist landing sites or multi-use runways, which could facilitate an increase in fly-cruise tourism operations, not only in the Antarctic Peninsula but potentially also in the Ross Sea in light of the new hard-rock runway near the Italian station.

Demand for Antarctic tourism is influenced by the disposable income available to those who have the time and/or opportunity and inclination to visit Antarctica (Kriwoken \& Rootes, 2000), and also by awareness of Antarctic tourism products, which is mediated by national Antarctic programmes, the media, scientists, other tourists, etc. (Powell, 2006). Changes in awareness and disposable income will have cascading effects on tourism demand.

On the supply side, the price and availability of fossil fuel (which is a significant component of operational costs), as well as the availability and continued seaworthiness of cruise ships (which needs to be considered, given that the fleet of vessels dominating the market at the moment is ageing; Bertram, 2007) are significant factors affecting the future development of Antarctic tourism. Supply might also be affected if overcrowding in certain parts of the Antarctic Peninsula causes a greater geographical dispersion of tourism operations. Overcrowding in the Antarctic Peninsula Region might also result in operators pushing further south or taking tourists into the Ross Sea region.

The regulatory environment for Antarctic tourism (including regulation by the ATCPs and through other international organisations and agreements, such as the International Maritime Organization, UNCLOS, the International Convention for the Prevention of Pollution from Ships [MARPOL], and the Convention on Biological Diversity [Antarctic and Southern Ocean Coalition, 2005; ATCM, 2012]) can either be a driving or a dampening force in Antarctic tourism development. The effectiveness of the current management framework for Antarctic tourism, which primarily consists of industry self-regulation, plays an important role in this regard. Future accidents or incidents, irrespective of whether they are a result of mismanagement or not, will have considerable consequences for discussions on how Antarctic tourism is managed and regulated in the future, especially if such incidents result in significant environmental or humanitarian consequences (Haase et al., 2009). Overall, the propensity of commercial operators to be(come) IAATO members and follow IAATO procedures and codes of conduct (Haase et al., 2009; Lamers, Haase, \& Amelung, 2008) is likely to play a moderating role in Antarctic tourism regulation and management.

Finally, it should not be forgotten that the degree to which national Antarctic programmes support tourism operations (for example, by offering use of their infrastructure or facilities, or by actively welcoming/inviting tourists) (Lamers et al., 2008; Mercopress, 2016) will also affect tourism development in Antarctica.

\section{Four scenarios for Antarctica}

From the above context we developed a set of key drivers for change in Antarctica over the next 25 years (Table 5). These were based on the sweep of futures literature which has been cited earlier plus our extensive experience in developing scenarios of this type and against which we superimposed a sensitivity analysis to determine what, at least currently, would be seen as the dominant patterns. Each driver will affect human engagement with the continent and its surrounding ocean in multiple ways. The impact of the drivers will vary significantly, with some (such as global power shifts or a global economic crisis) having wide-ranging top-down as well as bottomup impacts that can considerably change what happens in Antarctica. The drivers themselves are interdependent, with a shift in one driver affecting changes in another. The scenarios that have been developed result from a specific mix of individual drivers, their intensities and interactions. Consequently, the scenarios have to be considered as 
Table 5. Key drivers of change in the Antarctic realm to 2040.

\begin{tabular}{|c|c|c|c|}
\hline Drivers & Examples & Scale & $\begin{array}{l}\text { Impacts/implications for Antarctic } \\
\text { engagement }\end{array}$ \\
\hline $\begin{array}{l}\text { Global disruptions } \\
\text { (unexpected and often } \\
\text { catastrophic events) }\end{array}$ & $\begin{array}{l}\text { Water wars; terrorism; } \\
\text { global epidemics; global } \\
\text { financial crises }\end{array}$ & Global & $\begin{array}{l}\text { Shifting priorities in nation states, with } \\
\text { Antarctic science and operations } \\
\text { becoming less important; decreased } \\
\text { levels of funding for Antarctic } \\
\text { operations }\end{array}$ \\
\hline $\begin{array}{l}\text { Global power shifts (usually } \\
\text { slowly developing events } \\
\text { that change the current } \\
\text { global order) }\end{array}$ & $\begin{array}{l}\text { A weakening USA; demise } \\
\text { of the EU; rise of Asia } \\
\text { (the 'Asian century') }\end{array}$ & Global & $\begin{array}{l}\text { Destabilisation of existing coalitions in } \\
\text { the ATS; a stronger Asian influence; } \\
\text { impact on operational funding and } \\
\text { level of collaboration }\end{array}$ \\
\hline $\begin{array}{l}\text { Climate/environmental } \\
\text { change (noticeable but } \\
\text { gradual changes that will } \\
\text { eventually accelerate the } \\
\text { impacts of other drivers) }\end{array}$ & $\begin{array}{l}\text { Extreme weather events; } \\
\text { sea-level rise; } \\
\text { establishment of } \\
\text { non-native species }\end{array}$ & Global & $\begin{array}{l}\text { Increased operational risk (health and } \\
\text { safety; insurance); effects on } \\
\text { logistical assets (for example, bases } \\
\text { and runways) and on access to the } \\
\text { continent, diminishing the scientific } \\
\text { and wilderness values of Antarctica }\end{array}$ \\
\hline $\begin{array}{l}\text { Technological } \\
\text { advancement (of variable } \\
\text { speed but with potentially } \\
\text { significant impact on } \\
\text { operations) }\end{array}$ & $\begin{array}{l}\text { Remote science systems; } \\
\text { zero-emission } \\
\text { propulsion; closed-loop } \\
\text { energy generation }\end{array}$ & Global & $\begin{array}{l}\text { Direct effect on the cost of access to } \\
\text { and operations in Antarctica; affects } \\
\text { what kind of science can be } \\
\text { undertaken and where in Antarctica } \\
\text { (geographical extent of operations); } \\
\text { might also affect interest in Antarctic } \\
\text { resources }\end{array}$ \\
\hline $\begin{array}{l}\text { Cost of access (highly } \\
\text { elastic, with geopolitical } \\
\text { and economic } \\
\text { developments having a } \\
\text { direct effect on energy } \\
\text { costs; can fluctuate } \\
\text { rapidly) }\end{array}$ & $\begin{array}{l}\text { Energy (including fossil } \\
\text { fuel) price; the cost of } \\
\text { base operations; the } \\
\text { 'price of risk' }\end{array}$ & $\begin{array}{l}\text { Global/ } \\
\text { regional }\end{array}$ & $\begin{array}{l}\text { Affects insurance cover (and insurance } \\
\text { costs), the scale and scope of } \\
\text { operations, and the type of } \\
\text { vessels/aircraft operating in } \\
\text { Antarctica, with top-down effects on } \\
\text { what science can be done in the field }\end{array}$ \\
\hline $\begin{array}{l}\text { Interest in Antarctic } \\
\text { resources (likely to } \\
\text { change very slowly due } \\
\text { to considerable political } \\
\text { hurdles and pressures) }\end{array}$ & $\begin{array}{l}\text { Pressures to exploit } \\
\text { mineral or biological } \\
\text { resources on the } \\
\text { continent and in the } \\
\text { ocean, freshwater/ice; } \\
\text { potential degradation of } \\
\text { aesthetic resources } \\
\text { through increased } \\
\text { visitation }\end{array}$ & $\begin{array}{l}\text { Global/ } \\
\text { regional }\end{array}$ & $\begin{array}{l}\text { Changes in the level and nature of } \\
\text { human activities in the region (for } \\
\text { example, an increase in tourism } \\
\text { numbers or fishing vessels; presence } \\
\text { of drilling rigs); political pressures } \\
\text { (the ATS will be severely tested if } \\
\text { pressure to exploit resources } \\
\text { increases) and a possibly weakening } \\
\text { ATS (even if the need to exploit } \\
\text { resources in Antarctica disappears, } \\
\text { states may lose interest in } \\
\text { participating in the ATS) }\end{array}$ \\
\hline $\begin{array}{l}\text { Science funding } \\
\text { (semi-elastic and } \\
\text { responsive to changing } \\
\text { societal values and } \\
\text { economic pressures) }\end{array}$ & $\begin{array}{l}\text { Increased targeted science } \\
\text { funding; decreased } \\
\text { funding in formerly } \\
\text { dominant Antarctic } \\
\text { players }\end{array}$ & $\begin{array}{l}\text { Global/ } \\
\text { regional }\end{array}$ & $\begin{array}{l}\text { Effects on the nature of human } \\
\text { engagement in Antarctica and on the } \\
\text { actorscape (funding will determine } \\
\text { who the players will be); a potentially } \\
\text { emerging desire for private } \\
\text { sponsorship of Antarctic science } \\
\text { (with different rules) }\end{array}$ \\
\hline $\begin{array}{l}\text { Business interests (fast and } \\
\text { unpredictable as } \\
\text { businesses quickly follow } \\
\text { demand) }\end{array}$ & $\begin{array}{l}\text { Developments in tourism, } \\
\text { technology, exploration }\end{array}$ & Regional & $\begin{array}{l}\text { Affects the nature of human } \\
\text { engagement in Antarctica: possibly } \\
\text { changing tourism and bioprospecting } \\
\text { operations; business interests in } \\
\text { science or energy generation }\end{array}$ \\
\hline $\begin{array}{l}\text { Colonialist endeavours } \\
\text { (current status quo and } \\
\text { unlikely to change in the } \\
\text { short term) }\end{array}$ & $\begin{array}{l}\text { States wishing to obtain or } \\
\text { maintain a presence in } \\
\text { Antarctica (erection of } \\
\text { bases, airstrips, etc.) }\end{array}$ & Regional & $\begin{array}{l}\text { Changing levels of human activity and a } \\
\text { proliferation of bases; if states are } \\
\text { willing to give up their colonialist } \\
\text { interests, new possibilities for } \\
\text { collaborative operations in Antarctica } \\
\text { would result (with shared, } \\
\text { multinational bases) }\end{array}$ \\
\hline
\end{tabular}


Table 5. Continued

\begin{tabular}{|c|c|c|c|}
\hline Drivers & Examples & Scale & $\begin{array}{l}\text { Impacts/implications for Antarctic } \\
\text { engagement }\end{array}$ \\
\hline $\begin{array}{l}\text { Value sets among Antarctic } \\
\text { Treaty Parties (ranging } \\
\text { from conservationist to } \\
\text { exploratory, from } \\
\text { collaborative to } \\
\text { individualistic, from } \\
\text { passive to domineering) }\end{array}$ & $\begin{array}{l}\text { Newer ATS members may } \\
\text { be less interested in } \\
\text { conservation and } \\
\text { collaborative research } \\
\text { and more interested in } \\
\text { presence or exploitation }\end{array}$ & Regional & $\begin{array}{l}\text { Values are viscous and unlikely to } \\
\text { change quickly, but when they do } \\
\text { change they will have significant } \\
\text { implications for ATS governance, } \\
\text { Antarctic science, Antarctic } \\
\text { commercial interest and the legalities } \\
\text { around the exploitation of Antarctic } \\
\text { resources }\end{array}$ \\
\hline $\begin{array}{l}\text { Effectiveness of the } \\
\text { Antarctic governance } \\
\text { regime }\end{array}$ & $\begin{array}{l}\text { Implementation of the } \\
\text { Protocol; regulation of } \\
\text { Antarctic tourism; } \\
\text { regulation of Antarctic } \\
\text { fisheries; flexibility and } \\
\text { adaptiveness of the ATS } \\
\text { to new challenges }\end{array}$ & Regional & $\begin{array}{l}\text { Affects the extent to which political will } \\
\text { can be maintained, political interest in } \\
\text { a sustainable and sensible use of } \\
\text { Antarctica can be strengthened, and } \\
\text { political and financial capital are } \\
\text { invested in the ATS; the effectiveness } \\
\text { of the ATS will determine its } \\
\text { continued relevance }\end{array}$ \\
\hline $\begin{array}{l}\text { Public awareness about } \\
\text { Antarctica }\end{array}$ & $\begin{array}{l}\text { Level of media interest; } \\
\text { lobbying for Antarctic } \\
\text { conservation; interest in } \\
\text { tourism }\end{array}$ & Regional & $\begin{array}{l}\text { Implications for the level of investment } \\
\text { into Antarctic operations by } \\
\text { governments (with lobbying and } \\
\text { perceived societal priorities playing } \\
\text { an important role); affects } \\
\text { capacity-building in Antarctic } \\
\text { education, research and governance; } \\
\text { effects felt on NGO activity with an } \\
\text { Antarctic focus }\end{array}$ \\
\hline
\end{tabular}

dynamic, evolving possibility spaces that can be tweaked depending on the growing or diminishing importance of individual drivers.

On the basis of these main influencing factors four possible alternative futures or scenarios for Antarctica for the next two to three decades were developed by a process of postulating a series of possibilities arising across each of the main domains (global context, governance, tourism and research) to determine a series of four plausible and logically coherent scenarios with coherent narratives as described in detail below. In doing so, we sought to examine the possibility that the international community's engagement with Antarctica could be approaching - or may already have reached - a crossroads moment and how that might manifest itself. After several decades of negotiating and agreeing a series of international instruments to regulate activities in Antarctica (the regime development phase), the parties to those agreements have been going through a phase of regime implementation. And yet the region and the governance system face a series of challenges so serious that simple regime implementation may not be an adequate response.

A changing Antarctic climate is already driving changes in the abundance and distribution of native wildlife. Non-native species have established in the region and pose a risk to native biota. Human activity is increasing in the region through tourism and national Antarctic programmes, and the governance system is struggling to make progress on policy setting and decision-making in a number of key areas. For example, the Antarctic Treaty
Parties have yet to bring into force the Liability Annex to the Protocol, which was adopted in 2005. Progress within CCAMLR was very slow in addressing marine protection (though with some recent achievements), and the ongoing differences of views among the Antarctic Treaty Parties as to whether or not regulation of biological prospecting is required, not least as a result of increasingly divergent political interests in the region, stifles further action on that matter. Consequently, the future is uncertain for Antarctica, and any one of a number of future scenarios for the region may emerge. Currently the treaty parties place emphasis on the importance of Antarctic scientific research as the primary activity in the region for all the global knowledge and international diplomacy benefits that such efforts provide. Other activities (with economic benefits) are regarded as secondary.

Polar science may not remain the priority of governments in perpetuity. A shift in the balance of priorities may emerge through subtle but significant shifts in the perceived benefits that can be derived from a country's involvement in Antarctica. For example, we may see a 'peak science' that shifts the balance towards tourism as the primary activity in the region, which in turn may reach its own peak and open the way for much more commercially oriented resource exploitation and other uses of the region (such as bioprospecting, geoengineering, military use and communications activities).

The four scenarios that emerged were consistent with similar approaches in other domains (for example, Ebi et al., 2014) and were based on a fairly orthodox pair 
of axes, the $\mathrm{x}$-axis is based on a dominant global social perspective, ranging from individualistic to collaborative, and the y-axis expresses a global response to resources, ranging from conservationist to exploitative. In each quadrant the scenario reflects the combination of the main drivers combined into a coherent narrative. These can be summarised as:

- a collaborative-conservationist scenario that emerges from the various Antarctic actors extending and enhancing current governance arrangements, with environmental management and scientific research remaining the highest priorities for governmental engagement

- a collaborative-exploitative scenario that arises from continuing faith in the ATS, though with parties shifting their interests to a more utilitarian perspective

- an individualistic-conservationist scenario that results from the demise of the ATS, stemming from a slowdown in political and financial investment - research and environmental conservation remain, though with less interest from governments - resulting in less collaboration; this may be a transition state to more exploitativeoriented futures

- an individualistic-exploitative scenario emerging from a failing ATS - lack of political and financial investment sees parties having increasingly divergent views over Antarctica and governance becoming increasingly irrelevant, and parties act increasingly independently of the rules and with a focus on their own, more commercial, interests.

\section{The scenarios}

Detailed scenarios were derived from combining elements that arose in each of the main domains (Tables 1-5). Of the myriad of possibilities, we have developed those most plausible in relation to the future trends. The scenarios are not intended to be predictive but to illustrate potential future possibilities. As understanding of trends develops the scenarios will change. This will also happen if there are significant events outside the current relatively limited scope. However to be fully inclusive of all possibilities is well outside the scope of this paper though such exercises can take place such as under the Intergovernmental Panel on Climate Change (IPCC) climate change scenarios (Ebi et al., 2014; IPCC, 2014). These are outlined below to a common format with each having a narrative that summarises the main findings. Against this context we identified a series of interdependent drivers that will probably influence Antarctica's future (global context, governance, tourism and research) and developed four possible future scenarios based on variable application of the drivers, their intensities and potential interactions. The source material for these are the various citations given above and these have been excluded from Tables 1-4 for ease of reading. The resulting scenarios have to be considered as dynamic and evolving possibility spaces that can be adjusted, depending on the growing or diminishing importance of individual drivers.

\section{Scenario 1: Clean, white Antarctica - conservation's poster-child}

\section{Overview}

Antarctic actors continue to support and extend the current governance arrangements, with environmental management and scientific research remaining as the highest priorities for governments. Marine resource exploitation continues in a sustainable manner, with krill and finfish fisheries maintained within CCAMLR targets and a series of Marine Protected Areas are established throughout the Southern Ocean.

\section{Antarctic Treaty System}

There is increased investment in the ATS through increased resourcing of the Antarctic Treaty Secretariat and the development and implementation of a strategic programme of work for the Antarctic Treaty Parties, supported by enhanced internal cooperation among the ATCM, CEP and CCAMLR. Partners fulfil their global responsibilities through a more concerted programme of public outreach as well as efforts to engage with, and be represented at, other global bodies such as the IPCC, the Intergovernmental Science-Policy Platform on Biodiversity and Ecosystem Services (IPBES), the Convention on Biological Diversity and the World Meteorological Organization (WMO), and so on.

\section{Antarctic research}

Based on increased public acknowledgement of the global importance of Antarctic science, there is renewed investment in Antarctic science at national and international levels, with a strong emphasis on addressing The Scientific Committee on Antarctic Research's (SCAR) Horizon Scan questions and internationally established science challenges, as well as developing technologies and logistics to address those questions. Conservation science increases, through introduction of a tax on Antarctic tourism which supports more informed policy development, leading to more timely and deliberate Antarctic conservation planning and decision-making.

\section{Antarctic tourism}

A mature relationship is developed with the tourism industry, which results in enhanced research opportunities, including coordinated citizen science and a programme of sustainable growth in the industry, but with a peak in activity in about 2030 followed by a gradual decline.

\section{Scenario 2: Back to the future - something for everyone}

\section{Overview}

The ATS is supported as a regime for the collaborative management of resource exploitation. Marine exploitation has expanded on broadly sustainable terms, with diversification into marine bioprospecting and aquaculture. The 
CEP has a stronger role in regulating the activities of commercial operators. Such changes are vociferously resisted by environmental non-governmental organisations (NGOs), which are given a seat at the table to contribute to regulation through a partnership approach.

\section{Antarctic Treaty System}

This is strengthened through increased membership and the negotiation of additional resource management agreements, including rebirth of the Antarctic mineral resource convention and negotiation of a convention to regulate bioprospecting - both of which require new secretariats to be resourced. ATCM and CCAMLR are more aligned with their parallel interests in resource management. Through active, collaborative decision-making, the interest and attitudes of parties have shifted to a utilitarian perspective. Arguably this is where the parties were in the 1980s, with CCAMLR coming into force and the treaty parties spending six years negotiating the Antarctic mineral resources convention. Minimum environmental impact and sustainable exploitation remain key principles of the treaty parties.

\section{Antarctic research}

This is still important, but with a much stronger focus on technology development and testing to support responsible exploitation. SCAR has expanded its scientific objectives to include research into sustainable technologies for high-latitude resource exploration and exploitation. COMNAP has reassessed its role and changed its focus to providing education and training of new, more commercially oriented, operators and coordinating safety management and search and rescue.

\section{Antarctic tourism}

This continues to grow and diversify for a while, but reduces quickly with the reduction in wilderness values across the continent. Some niche and extreme tourism remains. IAATO is given more teeth by the Antarctic Treaty Parties, with genuine collaboration between tour operators and policymakers.

\section{Scenario 3: Gold rush Antarctica - buy now while stocks last}

\section{Overview}

There is a lack of political and financial investment in Antarctica, with increasingly divergent views over its future. Governance is increasingly stultified and irrelevant, resulting in a failing ATS. Governments have bilateral arrangements to exploit mutually beneficial commercial interests, including supporting private ventures and privately owned facilities. Environmental standards in the region are of secondary interest to companies and governments active in the region, and although environmental NGOs continue to protest against Antarctic exploitation, their voice is increasingly dismissed and unheeded.

\section{Antarctic Treaty System}

Parties are acting independently of the ATS rules, with a focus on their own interests. International collaboration has reduced, with a swift move to competition for resources. ATS and CCAMLR membership has become less attractive, and non-party states seek opportunities to establish activities in the region outside of the system.

\section{Antarctic research}

Science is a secondary interest, with SCAR weaker and becoming irrelevant. Research in technology to support exploration for, and exploitation of, Antarctic resources has emerged, based on a nationalist, competitive model. Public interest in Antarctica's intrinsic values has decreased, with public awareness focused on the commercial benefits being realised from individual states' activities in the region. A range of new entrepreneurial ventures has emerged, such as niche high-end bottled water industries or 1,000-year-old Antarctic ice collected and sold for the high-end cocktail market, and freshwater harvesting on a grander scale is being explored.

\section{Antarctic tourism}

Reduced cooperation among states has reduced the need for cooperation among tour operators and has resulted in a less regulated, more competitive industry. Rapid diversification of the industry results, with land-based facilities (for example, hotels) established and a wide range of visitor experiences on offer, such as golfing and theme parks.

\section{Scenario 4: My Antarctica - eat, sleep, freeze}

\section{Overview}

Despite good intentions and generally conservationoriented values, the lack of political and financial investment in the system sees Antarctica and Antarctic science becoming an increasingly irrelevant interest for governments globally. The ATS is in steady decline as a result of decreased political and financial investment in the system. Environmental NGOs continue to advocate for conservation of the last great wilderness but gain little traction with governments.

\section{Antarctic Treaty System}

There is a reduction in governments' investment in increasingly expensive Antarctic science, coupled with the parties' increasing inability to reach consensus on key policy matters (such as the establishment of Marine Protected Areas) and the failure of parties to bring into effect key decisions (for example, the Liability Annex to the Protocol). The parties hold meetings on a biennial rather than annual basis. The increasingly weak ATS means that other international bodies (for example, UNCLOS and Convention on Biological Diversity) more proactively and deliberately cover legal and policy issues related to Antarctica in their own agreements, further weakening the role of the ATS. Reduced public awareness of Antarctic issues results as the media lose interest in Antarctic matters 
and political commitment to the region becomes largely symbolic.

\section{Antarctic research}

Although scientific research and environmental management remain as the stated primary interests of most governments, reduced funding means international collaboration is harder to achieve. Science projects are small-scale, short-term and disparate, with many governments encouraging national Antarctic programmes to seek private investment to support their research. SCAR is weakened, with no traction to facilitate international research. Stateowned research bases struggle to justify their existence, reduce their focus on environmental management and are complemented - or possibly taken over - by a growing number of privately owned facilities exploring alternative uses of Antarctica's resources. Harvesting of Southern Ocean resources continues, initially at stable levels, but the lack of cooperation in monitoring and policing means that the rate of illegal, unreported and unregulated (IUU) fishing significantly increases.

\section{Antarctic tourism}

Land-based facilities have emerged (for example, hotels) to support niche tourism, such as escapes to spiritual havens that focus on 'last chance' wilderness experiences the region has to offer. IAATO loses traction and selfregulation through IAATO does not mean much anymore.

\section{Concluding comments}

The four scenarios presented above are intended to stimulate further discussion rather than provide predictions. It is assumed that change in the short term will be modest compared to the longer term (beyond 2050), and change, be it biophysical or in terms of governance in Antarctica, will generally be slow. Decisions over participating in Antarctic operations are not made lightly as Antarctica is likely to remain, at least for a decade, a challenging place to get to and work. Changes in existing national Antarctic programmes take time to have an effect, and the impacts arising from the scenarios we have developed are unlikely to be automatic or immediate. A changing global climate and its consequences for Antarctica's natural environment will have significant ramifications for the character and intensity of human engagement with Antarctica in the long term, and alternative futures that take account of these longer term global effects are useful indicators of potential paths in the future. Similarly, the impact of broader geopolitical dynamics is likely to fully play out only in the longer term (such as changes linked to a potential radicalisation of foreign policies with changes in elected governments), and would need to be considered further through more detailed Antarctic futures analysis.

Although there may be a fine line between different scenarios, certain drivers (for example, political will and investment) may tip the balance towards a particular possibility space. Scenarios 1 and 2 require investment and determined effort to move towards (a push), while scenarios 3 and 4 are somewhat inevitable if the parties do nothing and the status quo remains (a pull). Even if some of the developments in the scenarios appear tenuous, and may not play out in the way suggested, they offer an opportunity to test underlying assumptions. Currently many national Antarctic programmes assume an ongoing interest in Antarctic science. However, when faced with future pressures (for example, long-term droughts, epidemics, an influx of climate refugees, political tensions and increased flood events), will Antarctic science retain its urgency and importance? Will Antarctic science continue to be appealing to invest in, or will the slow rate of return/benefits arising from Antarctic operations eventually result in them becoming unappealing to governments? When will researchers cross a threshold into 'routine', less appealing research?

For scientists, and politicians, Antarctic research is still considered frontier science. It is unclear how long this possibly idealistic view of the world will be retained. Change is inevitable. It is unwise to continue to plan on major investments and research programmes that have been based on a model that could be irrelevant in the not-too-distant future. At a simple level, both the access to and cost of technology will mean that the way research is undertaken in Antarctica will change. Commercial pressures and a perceived need for 'unique visitor experiences' suggest that increases in Antarctic tourism, especially in the Ross Sea region, are inevitable. The growing world population and the need to feed it create greater pressures to fish where protected species currently exist, and potentially there might be debates about resource exploitation. It is foreseeable that governments will increasingly question the value of their investment in some Antarctic research programmes with some increasingly questioning how they can shape their future in Antarctica and influence other players. These are hard questions that challenge current Antarctic relationships and activities.

These hard questions suggest that researchers need to be more deliberate and rigorous in the development of polar futures, where both Arctic and Antarctic futures are based on complementary structures that draw on formal quantitative models such as that developed for climate change (Ebi et al., 2014) through the shared socioeconomic pathways (SSPs) database (Riahi et al., 2017), and with qualitative assessments through global literature. We emphasise again that the scenarios presented in this paper are not intended to be predictive but to provide a longer term integrated perspective on plausible developments in order to stimulate meaningful dialogue. As researchers, we have a responsibility to provide insights into future possibilities, irrespective of whether these align with our individual hopes and aspirations.

\section{Acknowledgements}

The work presented in this paper builds on earlier work commissioned and funded by the Antarctic Office, Christchurch, New Zealand, and would not have been possible 
without the Antarctic Office's support. This research was also supported by the Ross Sea Region Terrestrial Data Analysis research programme, funded by the Ministry of Business and Innovation, New Zealand, with contract number C09X1413. The authors also wish to thank Jana Newman for her comments when developing the scenarios in 2016 and Ray Prebble for his support in editing the manuscript.

\section{References}

Adam, B., \& Groves, C. (2007). Future matters: action, knowledge, ethics. Boston, MA: Brill Academic Publishers.

Antarctic and Southern Ocean Coalition. (2005). Some legal issues posed by Antarctic tourism (XXVIII ATCM information paper 71). Retrieved from www.ats.aq.

Arbo, P., Iversen, A., Knol, M., Ringholm, T., \& Sander, G. (2013). Arctic futures: conceptualizations and images of a changing Arctic. Polar Geography, 36, 163-182.

ATCM (Antarctic Treaty Consultative Meeting). (2016). Secretariat paper 5: five year forward budget profile. Buenos Aires: Antarctic Treaty Secretariat.

ATCM (Antarctic Treaty Consultative Meeting). (2012). CEP tourism study: tourism and non-governmental activities in the Antarctic - environmental aspects and impacts (ATCM XXXV working paper 22). Retrieved from www.ats.aq.

ATS (Antarctic Treaty System). (2017). ATS database. Retrieved from http://www.ats.aq/devAS/info_measures_listitem.aspx? lang=e\&id=331.

Augustine, N. R., Allen, T., Dorman, C. E., Ducklow, H. W., Gordon, B., Harrison, R. K., . . . Wall, D. H. (2012). More and better science in Antarctica through increased logistical effectiveness. Washington, DC: US Antarctic Program Blue Ribbon Panel.

Avango, D., Nilsson, A. E., \& Roberts, P. (2013). Assessing Arctic futures: voices, resources and governance. The Polar Journal, 3, 431-446.

Bastmeijer, K., \& Roura, R. (2004). Regulating Antarctic tourism and the precautionary principle. The American Journal of International Law, 98, 763-781.

Beck, P. J. (2014). The international politics of Antarctica. Abingdon: Routledge.

Bell, W. (1986). Foundations of future studies (Vol. 1). New Brunswick and London: Transaction Publishers.

Bertram, E. (2005). Tourists, gateway ports and the regulation of shipborne tourism in the wilderness regions: The case of Antarctica (PhD thesis). London: University of London.

Bertram, E. (2007). Antarctic ship-borne tourism: an expanding industry. In: Snyder, J., \& Stonehouse, B. (Eds.). Prospects for polar tourism. Oxon and Cambridge, MA: CABI Publications.

Bertram, E., Gunn, C., \& Stonehouse, B. (2007). The cruise of the MS Golden Princess in Antarctic waters, January 2007. Polar Record, 44, 177-180.

Bertram, E., Muir, S., \& Stonehouse, B. (2007). Gateway ports in the development of Antarctic tourism. In: Snyder, J., \& Stonehouse, B. (Eds.). Prospects for polar tourism. Oxon and Cambridge, MA: CABI Publications.

Bertram, E., \& Stonehouse, B. (2007). Tourism management for Antarctica. In: Snyder, J., \& Stonehouse, B. (Eds.). Prospects for polar tourism. Oxon and Cambridge, MA: CABI Publications.

Brooks, C. M. (2013). Competing values on the Antarctic high seas: CCAMLR and the challenge of marine-protected areas. The Polar Journal, 3, 277-300.
Bulkeley, R. (2010). The political origins of the Antarctic Treaty. Polar Record, 46, 9-11.

Butler, R. W. (1980). The concept of a tourist area cycle of evolution: implications for management of resources. Le Géographe Canadien, 24, 5-12.

CCAMLR (Commission on the Conservation of Antarctic Marine Living Resources). (2015). Report of the thirty-fourth meeting of the commission. Hobart, TAS: CCAMLR Secretariat.

Center for Health and the Global Environment. (2006). Climate change futures: health, ecological and economic dimensions. Boston, MA: Harvard Medical School. Retrieved from http: //ccsl.iccip.net/ccf_report_oct_06.pdf.

Chown, S. L. (2013). Antarctic Treaty System past not predictive. Science, 339, 141.

Chown, S. L., Brooks, C. M., Terauds, A., Le Bohec, C., van Klaveren-Impagliazzo, C., Whittington, J. D., . . McGeoch, M.A. (2017). Antarctica and the strategic plan for biodiversity. PLoS Biology, 15, e2001656.

Chown, S. L., Lee, J., Hughes, K. A., Barnes, J., Barrett, P., Bergstrom, D. M., . . W Wall, D.H. (2012). Challenges to the future conservation of the Antarctic. Science, 337, 158159.

Chua, N., Shah, R. M., Husin, Z. H., \& Rahman, H. A. (2015). Antarctic tourism: the responsibilities and liabilities of tour operators and state parties. Procedia-Social and Behavioral Sciences, 202, 227-233.

COMNAP (Council of Managers of National Antarctic Programs). (2016). Antarctic roadmap challenges. Christchurch: Council of Managers of National Antarctic Programs.

Conforti, B. (1986). Territorial claims in Antarctica: a modern way to deal with an old problem. Cornell International Law Journal, 19, 249.

Davis, R. A. (2014). The durability of the 'Antarctic model' and Southern Ocean governance. In: Stephens, T., \& VanderZwaag, D. (Eds.). Polar oceans governance in an era of environmental change. Cheltenham: Edward Elgar.

Dodds, K. (2006). Post-colonial Antarctica: an emerging engagement. Polar Record, 42, 59-70.

Dodds, K., \& Collis, C. (2017). Post-colonial Antarctica. In: Dodds, K., Hemmings, A. H., \& Roberts, P. (Eds.). Handbook on the politics of Antarctica. Cheltenham: Edward Elgar.

Ebi, K. L., Kram, T., van Vuuren, D. P., O'Neill, B. C., \& Kriegler, E. (2014). A new toolkit for developing scenarios for climate change research and policy analysis. Environment Magazine, 56, 6-16.

Fogarty, E. (2011). Antarctica: assessing and protecting Australia's national interests (policy brief - August 2011). Sydney: Lowy Institute for International Policy.

Frame, B. (2008). 'Wicked', 'messy' and 'clumsy': long-term frameworks for sustainability. Environment and Planning $C$ : Government and Policy, 26, 1113-1128.

Haase, D., Lamers, M., \& Amelung, B. (2009). Heading into uncharted territory? Exploring the institutional robustness of self-regulation in the Antarctic tourism sector. Journal of Sustainable Tourism, 17, 411-430.

Headland, R. K. (1992). Chronological list of Antarctic expeditions and related historical events. Cambridge: Scott Polar Research Institute.

Hemmings, A. D. (2014). Re-justifying the Antarctic Treaty System for the 21st century: rights, expectations and global equity. In: Powell, R. C., \& Dodds, K. (Eds.). Polar geopolitics? Knowledges, resources and legal regimes. Cheltenham: Edward Elgar.

Hodgman, P. (2016). Some capability and operating implications arising from Australia's Antarctic and Southern Ocean 
interests (soundings paper No. 10). Canberra: Sea Power Centre.

Hofman, R. J., \& Jatko, J. (Eds.). (2000). Assessment of the possible cumulative environmental impacts of commercial ship-based tourism in the Antarctic Peninsula area. La Jolla, CA: NSF, EPA, IAATO.

IPCC (Intergovernmental Panel on Climate Change). (2014). Climate change 2014: impacts, adaptation, and vulnerability. Part A: global and sectoral aspects. Contribution of Working Group II to the Fifth Assessment Report of the Intergovernmental Panel on Climate Change. Cambridge: Cambridge University Press.

Jabour, J. (2014). Strategic management and regulation of Antarctic tourism. In: Tin, T., Liggett, D., Maher, P. T., \& Lamers, M. (Eds.). Antarctic futures: human engagement with the Antarctic environment. Dordrecht, Heidelberg, New York, London: Springer.

Jabour, J. (2015a). Antarctic resources: topical issues. In: Loukacheva, N. (Ed.). Polar law and resources. Copenhagen: Nordic Council of Ministers.

Jabour, J. (2015b). The potential to regulate bioprospecting for marine genetic resources: two case studies. In: Warner, S., \& Kaye, S. (Eds.). Handbook of maritime regulation and enforcement. Abingdon: Routledge.

Jabour, J. (2017). Southern Ocean search and rescue: platforms and procedures. In: Dodds, K., Hemmings, A. H., \& Roberts, P. (Eds.). Handbook on the politics of Antarctica. Cheltenham: Edward Elgar Publishing.

Johansen, B. (2012). Leaders make the future: ten new leadership skills for an uncertain world. San Francisco, CA: BerrettKoehler Publishers.

Kennicutt, M. C., Chown, S. L., Cassano, J. J., Liggett, D., Massom, R., Peck, L. S., . . Sutherland, W. J. (2014a). Polar research: six priorities for Antarctic science. Nature, 512, 2325.

Kennicutt, M. C., Chown, S. L., Cassano, J. J., Liggett, D., Peck, L. S., Massom, R., . . S Sutherland, W. J. (2014b). A roadmap for Antarctic and Southern Ocean science for the next two decades and beyond. Antarctic Science, 27, 3-18.

Kennicutt, M. C., Kim, Y. D., Finnemore-Rogan, M., Anandakrishnan, S., Chown, S. L., Colwell, S., . . Yang, H. (2016). Enabling 21st century Antarctic and Southern Ocean science. Antarctic Science, 28, 407-423.

King, H. (2016, June 8). Human-carrying drone will start tests in Nevada. CNN Tech. Retrieved from http://money.cnn.com/ 2016/06/08/technology/ehang-drone-nevada/.

Kriegler, E., Edmonds, J., Hallegatte, S., Ebi, K. L., Kram, T., Riahi, K., . . van Vuuren, D.P. (2014). A new scenario framework for climate change research: the concept of shared climate policy assumptions. Climatic Change, 122, 401-414.

Kriwoken, L. K., \& Rootes, D. (2000). Tourism on ice: environmental impact assessment of Antarctic tourism. Impact Assessment and Project Appraisal, 18, 138-150.

Lamers, M., Haase, D., \& Amelung, B. (2008). Facing the elements: analysing trends in Antarctic tourism. Tourism Review, 63, 15-27.

Liggett, D. (2011). From frozen continent to tourism hotspot?: five decades of Antarctic tourism development and management, and a glimpse into the future. Tourism Management, 32, 357366.

Liggett, D., \& Stewart, E. J. (2017a). Sailing in icy waters: Antarctic cruise tourism development, regulation and management. In: Weeden, C., \& Dowling, R. (Eds.). Cruise ship tourism (2nd ed.). Wallingford: CABI.

Liggett, D., \& Stewart, E. J. (2017b). The changing face of political engagement in Antarctic tourism. In: Dodds, K., Hemmings,
A. D., \& Roberts, P. (Eds.). Handbook on the politics of Antarctica. Cheltenham: Edward Elgar.

Mason, P. A., \& Legg, S. J. (1999). Antarctic tourism: activities, impacts, management issues, and a proposed research agenda. Pacific Tourism Review, 3, 71-84.

Mason, P. A., \& Legg, S. J. (2000). The growth of tourism in Antarctica. Geography, 85, 358-362.

Mercopress. (2016, 27 July). Argentina planning tourist air tours of Antarctica beginning 2018. Retrieved from http:// en.mercopress.com/2016/07/27/argentina-planning-touristair-tours-of-antarctica-beginning-2018.

Moriarty, P., \& Honnery, D. (2014). Future Earth: declining energy use and economic output. Foresight, 16, 512-526.

Murray, C., \& Jabour, J. (2004). Independent expeditions and Antarctic tourism policy. Polar Record, 40, 309-317.

National Academy of Sciences. (2011). Future science opportunities in Antarctica and the Southern Ocean. Washington, DC: National Academy of Sciences.

Nelson, R. (2010). Extending foresight: the case for and nature of Foresight 2.0. Futures, 42, 282-294.

New Zealand. (2012). Repeat unauthorised commercial expedition: Nilaya/Berserk. ATCM XXXV working paper (WP 8). Hobart, TAS. Retrieved from www.ats.aq.

Norway. (2012). The Nilaya/Berserk expedition. ATCM XXXV information paper (IP 81). Hobart, TAS. Retrieved from www. ats.aq.

Pertierra, L. R., Hughes, K. A., Vega, G. C., \& Olalla-Tárraga, M. Á. (2017). High resolution spatial mapping of human footprint across Antarctica and its implications for the strategic conservation of avifauna. PLOS One, 12, e0168280.

Peterson, G. D., Cumming, G. S., \& Carpenter, S. R. (2003). Scenario planning: a tool for conservation in an uncertain world. Conservation Biology, 17, 358-366.

Pfeiffer, S., \& Peter, H.-U. (2003). Bestandsaufnahme und Managementpläne für zwei touristisch genutzte Gebiete der Antarktis - Grunddaten und Umweltindikatoren für die Entwicklung von Managementplänen für von Besuchern besonders stark frequentierten Anlandungsgebieten in der Antarktis [Survey and management plans for two tourist sites in the Antarctic - scientific basis and indicators for the development of management plans for frequently used visitor sites in the Antarctic]. Berlin: Umweltbundesamt.

Powell, S. (2006). Hotel Antarctica: what does the future hold for tourism in Antarctica? Australian Antarctic Magazine, 10, 2223.

Puig-Marco, R. (2014). Access and benefit sharing of Antarctica's biological material. Marine Genomics, 17, 73-78.

Randers, J. (2012). 2052: A global forecast for the next forty years. White River Junction, VT: Chelsea Green Publishing.

Reed, M. S., Kenter, J., Bonn, A., Broad, K., Burt, T. P., Fazey, I. R., . . . Raverak, F. (2013). Participatory scenario development for environmental management: a methodological framework illustrated with experience from the UK uplands. Journal of Environmental Management, 128, 345362

Reich, R. J. (1980). The development of Antarctic tourism. Polar Record, 20, 203-214.

Republic of Liberia. (2009). Report of investigation in the matter of the sinking of passenger vessel Explorer (O.N. 8485) 23 November 2007 in the Bransfield Strait near the South Shetland Islands. Monrovia: Bureau of Maritime Affairs.

Riahi, K., van Vuuren, D. P., Kriegler, E., Edmonds, J., O'Neill, B. C., Fujimori, S., . . . Tavoni, M. (2017). The shared socioeconomic pathways and their energy, land use, and greenhouse gas emissions implications: an overview. Global Environmental Change, 42, 153-168. 
Scott, K. N. (2015). Ice and mineral resources: regulatory challenges of commercial exploitation. In: Liggett, D., Storey, B., Cook, Y., \& Meduna, V. (Eds.). Exploring the last continent. Dordrecht, Heidelberg, New York, London: Springer.

Slaughter, R. A. (2008). Integral futures methodologies. Futures, 40, 103-108.

Splettstoesser, J. F. (2000). IAATO's stewardship of Antarctic environment: a history of tour operators' concern for a vulnerable part of the world. International Journal of Tourism Research, 2, 47-55.

Sridhar, R., Sachithanandam, V., \& Mageswaran, T. A. (2016). Political, economic, social, technological, legal and environmental (PESTLE) approach for assessment of coastal zone management practice in India. International Review of Public Administration, 21, 216-232.

Swanson, J., Liggett, D., \& Roldan, G. (2015). Conceptualizing and enhancing the argument for port state control in the Antarctic gateway states. The Polar Journal, 5, 361385.

Tin, T., Liggett, D., Maher, P. T., \& Lamers, M. (Eds.). (2014). Antarctic futures: human engagement with the Antarctic environment. Dordrecht, Heidelberg, New York, London: Springer.
Tracey, P. J. (2001). Managing Antarctic tourism (Unpublished PhD thesis). University of Tasmania, Hobart, TAS.

Turner, J., Barrand, N. E., Bracegirdle, T. J., Convey, P., Hodgson, D. A., Jarvis, M., . . Klepikov, A. (2014). Antarctic climate change and the environment: an update. Polar Record, 50, 237.

UNEP. (2015). Biannual report on the administration of the Convention on Biological Diversity. I. Nairobi: United Nations Environment Programme.

Watts, A. (1992). International law and the Antarctic Treaty System (Vol. 11). Cambridge: Grotius Publications.

Weeks, D., Malone, P., \& Welling, L. (2011). Climate change scenario planning: a tool for managing parks into uncertain futures. Park Science, 28, 26-33.

Woehler, E. J., Ainley, D., \& Jabour, J. (2014). Human impacts to Antarctic wildlife: predictions and speculations to 2060. In: Tin, T., Liggett, D., Maher, P. T., \& Lamers, M. (Eds.). Antarctic futures: human engagement with the Antarctic environment. Dordrecht, Heidelberg, New York, London: Springer.

Young, O. R. (2013). Arctic futures: the power of ideas. In: Berkman, P. A., \& Vylegzhanin, A. N. (Eds.). Environmental security in the Arctic ocean. Dordrecht: Springer.

\section{Appendix}

List of ATCPs (Source: Antarctic Treaty Secretariat http://www.ats.aq)

\begin{tabular}{|c|c|c|c|c|c|c|}
\hline Country & $\begin{array}{l}\text { Claimant } \\
\text { nation }\end{array}$ & $\begin{array}{l}\text { Entry into force of } \\
\text { the Antarctic Treaty }\end{array}$ & $\begin{array}{l}\text { Consultative party } \\
\text { status achieved }\end{array}$ & $\begin{array}{l}\text { Party to the } \\
\text { Protocol }\end{array}$ & $\begin{array}{l}\text { Party to } \\
\text { CCAS }^{a}\end{array}$ & $\begin{array}{l}\text { Party to } \\
\text { CCAMLR }\end{array}$ \\
\hline Argentina & $x$ & 23 Jun 1961 & 23 Jun $1961^{*}$ & $x$ & $x$ & $x$ \\
\hline Australia & $x$ & 23 Jun 1961 & 23 Jun $1961^{*}$ & $x$ & $x$ & $x$ \\
\hline Belgium & & 23 Jun 1961 & 23 Jun $1961^{*}$ & $x$ & $x$ & $x$ \\
\hline Brazil & & 16 May 1975 & 27 Sep 1983 & $x$ & $x$ & $x$ \\
\hline Bulgaria & & 11 Sep 1978 & 05 Jun 1998 & $x$ & & $x$ \\
\hline Chile & $x$ & 23 Jun 1961 & 23 Jun $1961^{*}$ & $x$ & $x$ & $x$ \\
\hline China & & 08 Jun 1983 & 07 Oct 1985 & $x$ & & $x$ \\
\hline Czech Republic & & 14 Jun 1962 & 01 Apr 2014 & $X$ & & \\
\hline Ecuador & & 15 Sep 1987 & 19 Nov 1990 & $x$ & & \\
\hline Finland & & 15 May 1984 & 20 Oct 1989 & $x$ & & $x$ \\
\hline France & $X$ & 23 Jun 1961 & 23 Jun 1961* & $x$ & $x$ & $x$ \\
\hline Germany & & 05 Feb 1979 & 03 Mar 1981 & $x$ & $x$ & $x$ \\
\hline India & & 19 Aug 1983 & 12 Sep 1983 & $X$ & & $x$ \\
\hline Italy & & 18 Mar 1981 & 05 Oct 1987 & $x$ & $x$ & $x$ \\
\hline Japan & & 23 Jun 1961 & 23 Jun $1961^{*}$ & $x$ & $x$ & $x$ \\
\hline Korea (ROK) & & 28 Nov 1986 & 09 Oct 1989 & $x$ & & $x$ \\
\hline Netherlands & & 30 Mar 1967 & 19 Nov 1990 & $X$ & & $x$ \\
\hline New Zealand & $X$ & 23 Jun 1961 & 23 Jun $1961^{*}$ & $x$ & & $x$ \\
\hline Norway & $x$ & 23 Jun 1961 & 23 Jun $1961^{*}$ & $x$ & $x$ & $x$ \\
\hline Peru & & 10 Apr 1981 & 09 Oct 1989 & $x$ & & $x$ \\
\hline Poland & & 23 Jun 1961 & 29 Jul 1977 & $x$ & $x$ & $x$ \\
\hline Russian Federation & & 23 Jun 1961 & 23 Jun $1961^{*}$ & $x$ & $x$ & $x$ \\
\hline South Africa & & 23 Jun 1961 & 23 Jun $1961^{*}$ & $x$ & $x$ & $x$ \\
\hline Spain & & 31 Mar 1982 & 21 Sep 1988 & $x$ & & $x$ \\
\hline Sweden & & 24 Apr 1984 & 21 Sep 1988 & $x$ & & $x$ \\
\hline Ukraine & & 28 Oct 1992 & 04 Jun 2004 & $x$ & & $X$ \\
\hline UK & $x$ & 23 Jun 1961 & 23 Jun $1961^{*}$ & $x$ & $x$ & $x$ \\
\hline USA & & 23 Jun 1961 & 23 Jun $1961^{*}$ & $x$ & $x$ & $x$ \\
\hline Uruguay & & 11 Jan 1980 & 07 Oct 1985 & $x$ & & $x$ \\
\hline
\end{tabular}

*Original signatory nation

aConvention for the Conservation of Antarctic Seals 
List of non-consultative parties to the Antarctic Treaty (Source: Antarctic Treaty Secretariat http://www.ats.aq)

\begin{tabular}{|c|c|c|c|c|}
\hline Country & $\begin{array}{l}\text { Entry into force of } \\
\text { the Antarctic Treaty }\end{array}$ & $\begin{array}{l}\text { Party to the } \\
\text { Protocol }\end{array}$ & $\begin{array}{l}\text { Party to } \\
\text { CCAS }\end{array}$ & $\begin{array}{l}\text { Party to } \\
\text { CCAMLR }\end{array}$ \\
\hline Austria & 25 Aug 1987 & & & \\
\hline Belarus & 27 Dec 2006 & $\mathbf{X}$ & & \\
\hline Canada & 04 May 1988 & $\mathbf{x}$ & $\mathbf{X}$ & $\mathbf{x}$ \\
\hline Colombia & 31 Jan 1989 & & & \\
\hline Cuba & 16 Aug 1984 & & & \\
\hline Denmark & 20 May 1965 & & & \\
\hline Estonia & 17 May 2001 & & & \\
\hline Greece & 08 Jan 1987 & $\mathbf{X}$ & & $\mathbf{X}$ \\
\hline Guatemala & 31 Jul 1991 & & & \\
\hline Hungary & 27 Jan 1984 & & & \\
\hline Iceland & 13 Oct 2015 & & & \\
\hline Kazakhstan & 27 Jan 2015 & & & \\
\hline Korea (DPRK) & 21 Jan 1987 & & & \\
\hline Malaysia & 31 Oct 2011 & $\mathbf{X}$ & & \\
\hline Monaco & 31 May 2008 & $\mathbf{X}$ & & \\
\hline Mongolia & 23 Mar 2015 & & & \\
\hline Pakistan & 01 Mar 2012 & $\mathbf{X}$ & & $\mathbf{X}$ \\
\hline Papua New Guinea & 16 Mar 1981 & & & \\
\hline Portugal & 29 Jan 2010 & $\mathbf{X}$ & & \\
\hline Romania & 15 Sep 1971 & $\mathbf{x}$ & & \\
\hline Slovak Republic & 01 Jan 1993 & & & \\
\hline Switzerland & 15 Nov 1990 & & & \\
\hline Turkey & 24 Jan 1996 & & & \\
\hline Venezuela & 24 Mar 1999 & 31 Aug 2014 & & \\
\hline
\end{tabular}

